\title{
TANULMÁNYOK
}

\author{
Nagy Egon
}

\section{Világrend-váltás a koronavírus-járvány árnyékában}

A 2020-ban ellenörizhetetlenül terjedö koronavirus járvány nemcsak gazdasági megpróbáltatásokat fog okozni a világ számára, hanem a gazdasági-hatalmi átrendezödések katalizátorává is válhat. Ez a kiinduló tézis annál is inkább megáll a lábán, mert a vírus terjedésének közepette egy rendkivüli vehemenciával kibontakozó, kölcsönös vádaskodásokra épülö kommunikációs háború bontakozott ki az Egyesült Államok és Kína között. Az egészségügyi globális vészhelyzetben Kina összességében válságállóbbnak tünik gazdasági értelemben, ami fölgyorsithatja az amerikai-kínai hegemóniaváltást a világpolitikában. Mindezt fölerösítik azok a belsö instabilitást tükrözö tünetek, melyek az amerikai társadalomban az elnökválasztás évében a fölerősödö békétlenség formáit mutatják, illetve az Európai Unióban dezintegrációs veszélyeket gerjesztenek. A tanulmány ezen kiindulópontok és részleteiben elemzett, a múltbeli fejlödést is vázoló premisszák mentén igyekszik igazolni azt a föltevésünket, hogy a növekvö antagonizmusok és gazdasági-hatalmi rivalizálás közepette hogyan bontakozhat ki a jövőben egy korlátozott, új hidegháború Kina és az Egyesült Államok között. Vázoljuk azoknak a hatalmi csoportosulásoknak a kontúrjait, melyek szorosabb vagy lazább szövetségek révén e fokozatosan kétpólusúvá bövülö új világrendben öltenek majd testet.

Kulcsszavak: kétpólusú világrend, korlátozott hidegháború, Egyesült Államok, Kína, szövetségi rendszerek, koronavírus-válság

JEL-kód:

\section{https://doi.org/10.32976/stratfuz.2020.19}

\begin{abstract}
Általános bevezető
Példátlan izgalmas kortanúként megélni olyan korforduló időszakokat, melyekről bízvást állíthatjuk, hogy a jövő évszázadok alakításában meghatározó kiindulópontként fogják majd számon tartani az elkövetkező generációk. A világpolitikai hegemóniaváltás bizonytalansággal, várakozásokkal (kivárással), szorongásokkal vagy reményekkel tölthet el minden olyan aktív és értő figyelőt, aki érzékkel, értően vagy puszta kíváncsisággal szemléli a fölgyorsult eseményeket.

A jelen értekezés kísérletet tesz fölvázolni a mozgásterek és kényszerpályák dialektikáját, mely meghatározza középtávon a világhatalmi sakkjátszmák kimenetelét, olyan katalizátorjelenségek folyományaként is, mint amilyen a globális egészségügyi válsághelyzetet kiváltó koronavirus-járvány. A járvány kimeneteléről, elhúzódásáról még sejtelmünk sem lehet jelen pillanatban, ezért felelötlenség lehet váteszi szerepben tetszelegni. Mindazonáltal a rövid távú hatásai is annyira drasztikus gazdasági következményekkel járhatnak, hogy tartós és irreverzibilis egyensúlytalanságokat, kibillenéseket okozhatnak a világgazdasági rendben, amelyek rányomhatják a bélyegüket a geopolitikai erőpróbákra is.

Feltevéseink abból indulnak ki, hogy az Egyesült Államok és Kína egyre egyértelmübben kibontakozó világpolitikai mérkőzése a gigászok harcára emlékeztető párviadallá alakul, melyben egy olyan erőegyensúly látszik kibontakozni, amely érzékenyen tartható csak fönn. Ez az erőegyensúly azonban mindenképp megőrzendő, mert ellenkező esetben végzetes
\end{abstract}


szereptévesztésből eredő konfliktusdominóba kergetheti a feleket, mely beláthatatlan következményekkel járhat a világbékére.

Központi fogalmunk, mellyel a leggyakrabban fogunk operálni, a Henry Kissingertől kölcsönzött világrend, melynek új egyensúlyi pontja meghatározó lesz a nemzetközi stabilitás és a béke fönntarthatósága szempontjából.

Az új világrend fejlődési perspektívája az amerikai-kínai kétpólusosság irányába hat, melynek növekvő antagonizmusa egy új hidegháború körvonalait látszik megrajzolni. Megítélésünk szerint egy, a korábbi hidegháborúnál átjárhatóbb világrendet formáló, nem ideáltipikus, de mindenképp egyensúlyi helyzetet teremtő esetleges új hidegháború kibontakozása is megfelelőbb alternatíva egy világégésnél. Ez valószínüsíti azt, hogy az újonnan kibontakozó kétpólusosság újból az elrettentésen, valamint a kölcsönösen biztositott megsemmisitö erőn alapuló egyensúlyi állapotban fogja megtalálni azt a választóvonalat, mely a béke fönntartásához elengedhetetlen. Ez a kétpólusos rendszer közötti rugalmasabb választóvonal, ha fönnmarad, biztosítani fogja a békés egymás mellett élés olyan föltételrendszerét, mely sokkal nagyobb társadalmi-gazdasági-kulturális átjárhatóságot fog biztosítani a hatalmi szempontok szerint elkülönülő szembenálló felek közt, mint a huszadik századi hidegháború ideológiai szembenállásra épülő vetélytársai közt. A mai, mélységében globalizált világ, a gazdasági, kulturális és környezeti globalizmus több szálon összefonódott viszonyrendszerével nem teszi lehetővé, hogy a szocialista és kapitalista világrend hidegháború alatti izolációja megismétlődjön az új kétpólusosság keretrendszerében. Ez más szóval azt jelenti, hogy a jövőbeni ellenséges országok és szövetségi rendszerek közt elképzelhetetlenek a hermetikusan lezárt határok, az emberek, áru, tőke és információ szabad áramlása ma már lényegesebben korlátozottan, csak bizonyos csekély számú stratégiai elemeiben szürhető. Magyarán sehol sem várható új vasfüggöny leereszkedése, de a két pólus, Kína és az Egyesült Államok, valamint szövetségi rendszereik között találni kell egy új, egyensúlyi modus vivendit.

Ennek fényében a tanulmány a jövőbeni két szuperhatalom és az általuk épített lehetséges világrend anatómiáját próbálja fölvázolni. A központi elemzés ilyen értelemben Kínára és az Egyesült Államokra fókuszál, illetve a holdudvarukban szerveződő regionális hatalmakra, melyek a két főhatalom másodlagos függvényeként szerepelnek csupán. A nyugati világrend az Egyesült Államok mellé rendeli az Európai Uniót és, meglátásunk szerint egyre inkább Indiát következésképp e hatalmi centrumok jövőbeli szerepkörét az Egyesült Államok erőterének vizsgálatába illesztjük. A fölsorolt centrumokat valószínüleg ki fogják egészíteni az Egyesült Államok köré tömörülö harmadlagos játékosok, úgy, mint Japán és az öböl-menti gazdag olajtermelő arab államok némelyike (Szaúd-Arábia, Egyesült Arab Emírségek, Bahrein, Jordánia).

Az antagonisztikus rivális Kína, analóg módon, középtávon Oroszországot tudhatja majd maga mellett komplementer, alárendelt hatalomként. Ezért Oroszországot ebben az egyenletrendszerben csak alárendelt másodhegedűsként, Kína függvényeként tudjuk értelmezni és, ennek megfelelően, a Kínai erőtér részeként ejtünk csak róla szót. Harmadlagos tényezők a Kína melletti koalícióban a hagyományosan Kína-partner Pakisztán, illetve egyre inkább Irán, azáltal, hogy a perzsa államot a Trump kormányzat páriává tette az atomalku egyoldalú fölrúgásával.

Természetesen a két körvonalazódó szembenálló blokk (még nem lehet teljességében konkretizálódott szövetségi rendszerekről beszélni) magukban hordoznak még néhány jelentősebb középhatalmi ambícióval vagy valós középhatalmi képességgel fölruházott aktort, akikről szintén szót ejtünk majd. 
1.táblázat: A világ vezető hatalmi centrumai bázisparamétereinek átnézeti, összehasonlító táblázata

\begin{tabular}{|l|c|c|c|c|}
\hline & $\begin{array}{c}\text { Népesség } \\
\text { (millió } \\
\text { fó) }\end{array}$ & $\begin{array}{c}\text { GDP } \\
\text { (milliárd } \\
\text { dollár) }\end{array}$ & $\begin{array}{c}\text { GDP/fö } \\
\text { (ezer } \\
\text { dollár) }\end{array}$ & $\begin{array}{c}\text { 2020-ra } \\
\text { prognosztizált } \\
\text { növekedés a } \\
\text { GDP } \\
\text { százalékában }\end{array}$ \\
\hline Egyesült Államok & 328 & 20810 & 63,5 & $-4,3$ \\
\hline Kína & 1404 & 15220 & 10,84 & 1,9 \\
\hline Európai Unió 27 & 447 & 15600 & 34,8 & $-7,6$ \\
\hline Oroszország & 143 & 1460 & 9,97 & $-4,1$ \\
\hline
\end{tabular}

Forrás: imf.org

A fönti táblázatban összefoglalt alapmutatók híven tükrözik az aktuális kiinduló állapotokat az egyre elkeseredettebb globális hatalmi erőpróbában, ami a fő akciócentrumok között kibontakozóban van. Ez egyértelmủen igazolja Kína megnövekedett súlyát, mely az elmúlt négy évtized belső reformjainak és a globalizációs, gazdasági liberalizációnak a páratlanul sikeres egyvelegeként jöhetett létre. Kína mára államkapitalistának nevezhető berendezkedése teljesen megszabadult a merev, sztálinista voluntarizmustól, és a fönnmaradt ötéves tervezés is egy tőkés rendszerben megvalósuló hiperracionális gazdaságpolitika kivetülése. A globalizmus által előtérbe helyezett, globális termelési láncokra és outsourcing-ra épülő kínai növekedési modell nagymértékben alapozott a konfuciánus-taoista fegyelemre, munkamorálra és a tudásra-tanulásra, mint erényekre, amit halmozott versenyelönnyé konvertált a nemzetközi gazdaság színterén. Mindazonáltal megállapítható, hogy közeljövőben valószínủleg egyetlen hatalom sem éri majd el a globális GDP legalább 30 százalékát, magyarán a világgazdaság is egyre inkább egy multipolárisabb fejlődési irány felé mozdul el.

Ugyanakkor a koronavírus-járvány első szakaszában a kilábalási esélyek is Kínának kedveznek, mert, bár „megtépázódtak” korábbi impozáns növekedési mutatói, a világközpontok közt lényegében egyedül maradt Kína a pozitív növekedési tartományban. A járvány kiváltotta átmeneti gazdasági visszaesések tekintetében is mérsékeltebbek a kínai veszteségek, ugyanis 2020 januárjában, mikor a járvány következtében a kínai gazdasági zsugordás a mélypontját érte el, ez is mindössze -6,8\% volt, szemben az Egyesült Államok 2020 második negyedévi -31,4\%-os GDPmélyrepülésével szemben (Forrás: tradingeconimics.com, cnbc.com). Ezekben a trendekben szerepet játszanak a bázisadatok is, a kínai kiinduló mutatók által biztosított nagyobb gazdasági lendület utóhatásai. Ugyanakkor nem tekinthetünk el az érett piacgazdaságok nagyobb válságérzékenységétől sem azáltal, hogy a szolgáltató ágazatokra való domináns támaszkodás, ilyen zsugorodási időszakokban nagyobb sérülékenységet okoz, ugyanakkor a döntően földolgozóiparra építő gazdaságok válságállóbbnak bizonyultak. Megjegyzendő, hogy az Amerika koordinálta szövetségi rendszer belső magját képező Európai Unió visszaesése is számottevő - a 2020-as évre elörevetített zsugorodása a legnagyobb mértékü a szóban forgó szereplő közül (-7,6\%).

A hatalmi harcok politikai és kulturális modellek egymásnak feszülését is jelentik, ugyanis az Egyesült Államok köré szerveződő hatalmi centrum a részvételi demokrácia, a joguralmi modell és az egyéni szabadságjogok primátusát helyezik előtérbe a Kína köré szerveződő hatalmi centrum által preferált autokrata, felülről irányított demokrácia, jóval központosítottabb társadalomszervezési mintázataival szemben. Ilyen kontextusban, a vázolt társadalomfilozófiai töréspontokat a fönnálló modellek közt beilleszthetjük a Dani Rodrick-féle globalizációs trilemma-modellbe is (Forrás: https:/www.youtube.com/watch? $\mathrm{v}=\mathrm{SzVrKJ}$ rvmjA). 
Ez a modell a jelenkori globális társadalmi-gazdasági folyamatokat három fő vezérlő komponens köré szerveződve magyarázza, melyek közül csak kettő érvényesülhet teljességében szimultán, miközben a harmadik komponens kizáródik vagy konfliktusban áll a másik kettővel. E három komponens a demokrácia, a globális világgazdasági beágyazottság és a nemzeti szuverenitás. Az Egyesült Államok köré szerveződő erőtérben, a Nyugathoz tartozó magállamokban, kis hangsúlyeltolódásokkal a belső demokratizmus és a világgazdasági globalizmus elfogadása együtt érvényesül, miközben a szuverenitásuk bizonyos elemeit föladják a kompromisszumos közös döntéshozatal oltárán és a belső elitjeik nagyrészt lemondanak a kapitalista fejlődésből kivonható járadékok fölötti ellenőrzési jogról. Ezzel szemben a kínai vagy orosz modellben egy jóval centralizáltabb, szélesebb mozgástérrel bíró és korruptabb kormányzati modellben a demokratikus jogok csorbulnak, de ez az állammodell is teljesen betagozódik a neoliberális elvek mentén szerveződő gazdasági globalizmusba. A szuverenitás és demokrácia szimultaneitása pedig a múlté, mert a hiperglobalizációt megelőző brenton woods-i rendszer sajátja volt, mikor a Nyugat a legutolsó nagy prosperitási hullámot érte meg, a második világháborút követő gazdasági boomot meglovagolva. A két rivalizáló hatalmi tömb kontúrjai annál is inkább kirajzolódnak, mert mélyülni látszik a köztük fönnálló értékalapú, ideológiai összetűzés a demokrácia szerepét és értelmezését illetően.

\section{Kína - a feltörekvő hatalom kihívása}

Kína egy négyezer éves civilizáció örököse és a mai, magát kommunistának mondó rezsim is az úgynevezett „középső birodalom”, a Sang-dinasztiától müködő államalakulat jogutódjaként definiálja önmagát. Az ókori királyságok egységesítését Csin Si Huang-ti hajtotta végre Kr. e. a 3. században - ekkortól beszélhetünk Kínai Birodalomról a Csin dinasztia idejéből. A kínaiak történelmük során ügyes fondorlattal úgy védekeztek az idegen behatolókkal szemben, hogy kitértek a nyomásuk elöl és reziliens módon, rugalmas ellenállást tanúsítva végül magukba olvasztották a behatolókat. Ez történt a 13. századi mongol betörés idején és a 17. századi mandzsu invázió idején. Mindennek az alapját az az attitüd képezi, melyet a kínaiak az ókori híres stratégájuktól és filozófusuktól, Szun-ce-től tanultak, aki Kr. e. a 6. században élt és alkotott. Szun-ce azt tanította, hogy egy csatában legokosabb kivárni azt a pillanatot, hogy az ellenfél végzetes hibát kövessen el, és azt követöen, hirtelen lecsapva döntő vereséget kell mérni rá (Kissinger, 2014, p. 120). Az álcázó, megtévesztő, óvatosságra épülő taktika, valamint az ellenségek egymás ellen való kijátszása, illetve a türelmes hozzáállás szintén a szun-ce-i tanokból vezethető le. Ezzel a magatartással élte túl Kína a 19. századi megaláztatásokat, melyek az első és második ópium-háborúval kezdődtek. Ezt az időszakot nevezzük a megaláztatások korszakának 1839 és 1949 között (Gernet, 2005, p. 428). A kínai nemzeti ébredés egyik lépcsőfokát képezte a boxer lázadás, melyet az európai és japán gyarmatosítók koalíciója vert le 1900-ban. Ezt követte a szintén a gyarmatosítás keserü tapasztalataiból táplálkozó 1911-es forradalom, mely azonban már a külső elnyomással szembeni belső tehetetlenség ellen irányult és a mandzsu eredetü Csingdinasztia bukásához vezetett. Ez a Szun Jat-szen vezette, császárságot megbuktató fölkelés már a republikánus nacionalizmus jegyében folyt. Ezt követően a nacionalista tábor belső riválisokat kapott a két világháború közt a bolsevik eszmék behatolásával egyidejüleg, és az időszak a Csang Kaj-sek vezette Kuomintang nacionalista csoportosulás, illetve a Mao Ce-tung irányította kommunisták között zajló polgárháborúval írható le. Közöttük átmeneti tüzszünetet és taktikai szövetséget idézett elő a japán invázió és a második világháború végigharcolása a japán megszállók ellen 1936 és 1945 között. Kína a 19. századi koncessziós területekre való felosztást félgyarmati státusban élte meg, de ugyanígy a japán megszállók sem tudták teljességében meghódítani és „megemészteni” az óriásországot. Kínát a védekezésben, ellenállásban és túlélésben nemcsak a szun-ce-i tanok alkalmazása segítette, hanem az ország „feneketlen zsák” jellege, vagyis az Oroszországhoz hasonlatos stratégiai mélység, ami egy „heartland-szerü” hátország meglétét jelentette, ahova stratégiai visszavonulást eszközölhettek a kritikus időszakokban. 
A japánok kiüzését követően 1945-ben kiújult a kommunisták és nacionalisták párharca, amiből a Mao Ce-tung vezette gárda került ki győztesként és 1949-ben kikiáltották a szárazföldi Kínán a sztálini ihletésű Kínai Népköztársaságot. A Kuomintang egységei, Csang Kai-sek vezetésével Tajvan szigetére vonultak vissza, ahol egy független, szakadár államot alapítottak meg, Kínai Köztársaság hivatalos néven. Tajvant a világ államainak többsége nem ismeri el, mert kínai retorzióktól tartanak Tajvan diplomáciai elismerése esetén. A Kínai Népköztársaság ugyanis ragaszkodik az „egy Kína” elvhez és igényt tart a szigetre is, amelynek függetlenségét nem ismeri el.

A kommunista párt mao-i uralma idején a kínai fejlődés egy vargabetűkkel tarkított, tragikus, voluntarista fordulatokban gazdag eseménysorozaton ment keresztül. Az első ötéves tervek kezdeti sikerein fölbuzdúlva, az irracionális, akaratlagos gazdaságpolitika a munkaerő minél átfogóbb, extenzív mozgósítása által kívánta a Nyugatot mihamarabb utolérni egy olyan dugába dőlt modernizációs kísérlettel, amely a „nagy ugrás” néven vonult be a történelembe, és amely 1958 és 1965 között tartott (Horváth-Probáld-Szabó, 2008, p. 467). Ennek a kudarcos fölzárkózási kísérletnek az általános ínség és egy több mint 20 millió áldozatot követelő éhínség lett a következménye.

A ,nagy ugrás” egyértelmü tragikus következményét leplezendő, Mao figyelemelterelő jelleggel és a permanens forradalom igényétől vezéreltetve le akart számolni teljesen a „múlt Kínájával", annak konfucianista gyökerü hagyományaival. Példátlan értelmiség-üldözésbe kezdtek és a régi kommunista káderek egész sorát börtönözték be, vagy küldték átnevelö táborokba. Az akciót az úgynevezett fanatizált „,örös inges” pártkatonákkal hajtatták végre, pillanatra sem hagyva lélegzetvételnyi pihenőt az állandósult forradalomra „idomított” kínai tömegeknek. Mao uralmának utolsó fázisában a két kommunista hatalom, Kína és a Szovjetunió kapcsolata oly mértékben megromlott, hogy határvillongások törtek ki és a szovjetek már megelőző atomcsapást akartak mérni a lop nor-i kínai atomlétesítményekre. Ekkor lépett a színre Nixon amerikai elnök zseniális nemzetbiztonsági főtanácsadója és későbbi külügyérje, a kiváló tárgyalástechnikát alkalmazó Henry Kissinger, aki előkészítette a kommunista Kínába a történelem első amerikai elnöki látogatását és a kétoldalú amerikai-kínai kapcsolatok újbóli fölvételét 20 esztendő kihagyás után. Ez a kapcsolatfölvétel kihasználta mindkét fél számára előnyös módon a kínai-szovjet kapcsolatok megromlását - Kínát kivonta korábbi elszigeteltségéből és biztosította a hátországát egy szovjet agresszió esetére, míg az Egyesült Államok gyengíthette a szocialista tömböt, rést ütve a szovjetek világrendszerén, egyben gazdasági kapcsolatokat is nyitva egy addig kihasználatlan piaci célpont irányába. Ahogy Kissinger kiegyensúlyozottan fogalmazott, az Egyesült Államok akkoriban közelebb állt a két rivális kommunista hatalomhoz külön-külön, mint ahogyan azok egymáshoz viszonyultak.

Ezt a nyitást követte 1979-ben, Carter elnök idején a diplomáciai kapcsolatok fölvétele, amiben fontos szerepet játszott idősebb George Bush, egykori amerikai elnök, aki ezt megelőzően diplomáciai összekötőként szolgált Pekingben, ezt követően pedig a CIA elnöke lett.

$\mathrm{Az}$ államszocializmus nyolcvanas évekbeli nemzetközi mélyrepülése idején, majd a kilencvenes években a szocialista világrendszer összeomlása után Kína és az Egyesült Államok viszonyát egy korrekt és konstruktív partnerség jellemezte. Kína fejlödése azután pörgött föl igazán, miután 2002-től amerikai beleegyezéssel a Kereskedelmi Világszervezet (WTO) tagja lett, a globalizáció ugyanis a félperiféria államoknak jelentett kivételes gazdasági fölhajtóerőt akkoriban. A szabadkereskedelem rövid idön belül az élvonalba röpítette Kína gazdaságát, a világ első kereskedő nemzetévé avanzsálva, hatalmas többleteket halmozva föl kereskedelmi partnereivel szemben és ebből nagyfokú eredeti tökefölhalmozást hajtva végre a folyamatosan aktív folyó fizetési mérleg révén is.

A kínai külpolitika mind a mai napig követi a szun-ce-i hagyományokat, úgy ahogyan azt Teng Hsziao-ping fogalmazta meg plasztikusan, számítóan kiváró alapállásra intve kortársait: „Higgadtan figyeljünk; biztosítsuk a pozícióinkat; józanul mérjük föl az eseményeket; rejtsük el a képességeinket és várjuk ki, amíg eljön a mi időnk; legyünk visszafogottak, s soha ne akarjuk a vezető szerepet" (idézi: Brzezinski, 2013, p. 119). Tengnek tulajdonképp sikeres volt az a 
modernizációs kísérlete, amely ugyanolyan célzattal indult, mint a kudarcos gorbacsovi kísérlet a Szovjetunióban, jóllehet, Kína sokkal homogénebb nemzetiségi térszerkezete lényegesen jobban a kohézió belső megóvását eredményezte, szemben a szovjet centrifugális erők sokaságával.

Kína elmúlt négy évtizedes fölemelkedését a teng-i nyitást követően végig ez a szerény vagy álszerény magatartás jellemezte, hogy az ország ne vonja magára a külvilág ellenszenvét és irigységét, hogy semmilyen ellenszél ne akadályozza a kínai gyors konvergenciát a fejlett világhoz. A 2010-es évektől kezdve azonban az üstökösszerü kínai növekedés egyre inkább kiváltotta az amerikai féltékenységet atekintetben, hogy a világrend vezető szerepének és diktáló államának szerepkörét ki fogja a jövőben betölteni. Ez a féltékenység nemcsak az amerikaik részéről jelentkezik, hanem félelemmel vegyes távolságtartást vált ki olyan hagyományos regionális riválisokból, mint Japán, India, Vietnám és Dél-Korea. De a tágabb ausztro-ázsiai régióban Ausztrália és Új-Zéland is régóta táplál egy olyan félelmet, hogy északról hatalmas áradatban mongoloid népesség fogja elözönleni - és ezt a valós vagy képzelt fenyegetést ugyancsak Kína testesíti meg leginkább számukra.

A jelenkorban Kína fö geopolitikai expanziós irányát a Csendes-óceán felé való kitörés szándékával írhatjuk le, merthogy a környezetében lévő kisebb államok növekvő fóbiája az új kínai óriástól szerves dialektikában bontakozik ki Kína azon félelmével egyidőben, hogy a föntebb fölsorolt környezö államokat fölhasználva az Egyesült Államok tulajdonképp Kína stratégiai bekerítésén dolgozik. Ez a kínai félelem még inkább igaz volt akkor, amikor az Obama kormányzat a TPA (Transz-csendes-óceáni Partnerség) egyezményt tető alá hozta és nagy megkönnyebbülést jelentett a kínaiak számára annak fölmondása Trump elnök alatt. Sokan e cselekedet miatt, akkor kifordították Trump elnök 2016-os hazai kampány-hívószavát, oly módon parafrazálva azt, hogy „Make China great again”. Ennek jegyében is, 2020-ra Kína sikeresen végrehajtott egy olyan flottafejlesztést a progresszíven növekvő katonai összkiadásainak keretében (amelyek a GDP 2\%-a körül mozognak jelenleg), aminek a révén a hadihajók számában már megelőzte az Egyesült Államokat, ennek ellenére a flottájának a tüzereje és technológiai szintje még mindig jelentősen elmarad az amerikaiétól. Mivel a jövőben Kínának fö ellenfélként egy maritim hatalommal kell megmérkőznie és hatalmi kiterjesztésének elsődleges iránya a Csendes-óceán, ezért a haditengerészet kiemelt fontosságúvá vált a kínai „power projection” tervezetekben. Láthatóan Kína nem kívánja megismételni a 15. század eleji stratégiai hibáját, amikor a Ming dinasztia idején Cseng Ho admirális flottáját nem fejlesztette tovább ütőképes haditengerészetté és ezzel lemondott a más földrészek felé való terjeszkedésről, átengedve a terepet az európai gyarmatosítóknak (Kennedy, 2011, pp. 29-30).

Gazdasági vonatkozásban Kína távlatos fejlődése nagyban fog arra alapozni, hogy az ország további pozíciókat vívjon ki magának a jövő digitális gazdaságának szervezésében. Számos területen sikerült egy olyan státust kiharcolnia magának, ami az innovációkat diktáló kulcsszereplő pozíciójának felel meg - gondoljunk csak a Huawei által kézben tartott legfejlettebb, az üzleti élet digitalizációját meghatározó $5 \mathrm{G}$ mobiltechnológiára. Nem véletlen, hogy az Egyesült Államok éppen a Huaweit igyekszik kiszorítani ebből a játszmából és nemzetbiztonsági megfontolásokból is arra készteti szövetségeseit, hogy az érzékeny információk védelme érdekében tartózkodjanak a kínai távközlési óriással való együttmüködéstől. Válaszlépésként Kína és Oroszország elhatározták, hogy közösen, a legrövidebb időn belül megkísérlik egy, az Androiddal versenyképes alternatív operációs rendszer kidolgozását, amivel függetlenítik magukat és termékeiket az amerikai szoftver-monopóliumtól.

Ugyanakkor a fölgyorsuló digitalizáció és automatizáció megnöveli a termelési láncok integrált kezelésének a lehetőségét. Ez fölértékeli a termelési kapacitásoknak a felvevőpiac-közeli elhelyezését, ami egy relokalizációs forradalmat indíthat el. A pandémia is rávilágított arra, hogy a járvány miatti termeléskiesések, a térben szétforgácsolt termelö-alegységek által indukált növekvő fertőzési kockázatok is az onshoring felé mozdíthatják el a gazdasági tevékenységek lokalizációját. Nem utolsó sorban a járvány újabb lökést adhat az automatizációnak, mely csökkenti az ágazatok kitettségét a munkaerőt sújtó biológiai veszélyeknek, és a robotizáció tovább erősítheti azt a tendenciát, hogy a termelőkapacitások újból a centrumországokban, a 
kereslethez igazodva lesznek térben elhelyezve, ugyanis itt már nem lesz szempont az alacsonyabb bérköltség, csak a nagyobb szállítási költség minimalizálása. Az új lokalizációk stratégiai szempontokat is követhetnek, párhuzamosan azzal, hogy bizonyos korábbi telephelyek bérelőnyei „elolvadnak”. Jó példa erre az amerikai „Apple” cég termelőkapacitásainak relokalizációja Kínából Indiába. Az Egyesült Államok ezzel egy jövőbeni potenciális szövetségest támogat egy egyre inkább ellenségként kezelt országgal szemben, amely felé ráadásul a technológia-transzfer lehetőségét is meg kívánja gátolni. Kína indusztrializációra tervezett, intenzív élömunkabefektetésen alapuló fölzárkózási modellje sokkal sikeresebbnek bizonyult az indiai modellnél, mely az iparosítási fázis kvázi ,átugrásával” kívánt modern, szolgáltatói társadalmat létrehozni. A pandémia utáni közvetlen külföldi tökebefektetések igyekeznek stratégiai megfontolásokból a szövetséges, és ráadásul nagyobb bérmegtakarítással kecsegtető országok felé orientálódni. Ez utóbbi tőkeáramlási mintázat jó alkalmat jelenthet India számára is, hogy a rivális Kínával szemben valamelyest ledolgozzon a fejlődési hátrányából.

Kína, a fönti tendenciákat figyelembe véve, veszteséget könyvelhet el a kiszervezett munkahelyeket illetően, melyek eddig exportra termeltek és meghatározó szerepük volt Kína gazdasági hatalommá emelésében. De a kínaiak már korábban is hosszú távra terveztek és a 2020 október végi pártkongresszusán a Kínai Kommunista Párt kijelölte az endogén növekedési erőforrásokra és belső fogyasztásra jobban alapozó jövőbeni fejlődési pályát. Ennek megfelelően Kína a jövőben fokozatosan letér az exportvezérelt növekedésről, és a külső kényszerek miatt is, egyre inkább a belső piac ellátására koncentrál, fölpörgetve a belső fogyasztást. Ez azt jelenti, hogy folytatja a már korábban megkezdett tendenciát, hogy igyekszik saját, versenyképes transznacionális vállalatokat kiépíteni és jól bevált nyugati brandeket fölvásárolni, hogy a digitalizált, integrált termelési láncok csúcsán helyezkedjen el, ahol a profitrealizálás megvalósul. Ez egyértelmüen a korábbi egyszerü fizikai munkafolyamatokra alapozó, alacsonyabb hozzáadottértékü termelési szegmensek háttérbe szorulását, és ezeknek a kínai gazdasági erőtér feltörekvő partnerországaiba való kiszervezését eredményezi majd. A növekvő belső fogyasztás vélhetően nem fedezhető szabadpiaci körülmények között csupán belső forrásokból, így növekvő importigénnyel is párosulni fog. Ennek megfelelően Kína a növekvő kereslete révén stabilizáló szerepet játszhat a világgazdaságban, munkát adva az általa preferenciálisan kiválasztott importőröknek, növekvő exportjövedelemhez juttatva eddig - többek közt a kínai konkurencia miatt is - háttérbe szoruló szereplöket. Ez több szempontból is stratégiai előnyt jelent Kína számára. Egyrészt hatékonyabban üthet vissza az ellene irányuló kereskedelmi háborúkban, hiszen például az aránytalanul nagy kínai külkereskedelmi aktívum miatt Kína nem volt képes arányosan visszaütni az Egyesült Államoknak az Amerikából származó import korlátozásával. Másrészt vásárlóként is növelve a súlyát a nemzetközi kereskedelemben, egyértelmüen és hatékonyabban elősegítheti középtávú céljának a megvalósulását, ami a renminbiből nemzetközi kulcsvalutát alkotna az amerikai dollár háttérbe szorításával. Ez a pénzügyi hegemóniaváltás a jövőben lehetetlenné tenné az amerikai pénzügyi szankciók életbe léptetését, drasztikusan csökkentve Amerika világhatalmi mozgásterét és érdekérvényesítő képességét. Mindehhez még az is szükségeltetik, hogy Kína saját alternatív digitális pénzügyi transzferrendszereket építsen ki, amely tervéhez szintén kapott orosz együttmüködési fölajánlást.

Paradox módon, éveken át épp az Egyesült Államok kérte ismételten Kínát, hogy nagyobb importrészesedéssel és a valutája fölértékelésével vegye ki a részét a külkereskedelmi aszimmetriák csökkentésében, ami azonban elindíthat egy olyan folyamatot, ami az amerikai dollár távlatos „trónfosztását” eredményezheti. Kína most érkezett el egy olyan gazdasági „érettségi” szintre, amikor már megengedheti magának a stabilabb, sőt növekvő nemzeti valutaárfolyamot, és ezáltal kedvezőbb kamatkörnyezetben juthat hitelhez is, és egyre inkább tartalék-, illetve menedékvalutaként kezdenek majd tekinteni a renminbire (Forrás: https://novekedes.hu/elemzesek/mikor-lesz-a-kinai-juan-a-kovetkezo-dollar). Ugyanakkor az a föltevés nemigen állja meg a helyét, hogy a jobbára amerikai eszközökben elhelyezett Kínai nemzetközi tartalékok egy túlzottan jelentős gazdasági zsarolási, vagy tömeges piacra dobásuk esetén hatékony gazdasági válaszcsapási lehetőséget jelentenének Kína számára az Egyesült 
Államokkal szemben, hiszen ezáltal Kína saját tartalékait értéktelenítené el, saját magának is tetemes anyagi károkat okozva.

Egyre fontosabb dimenzió Kína nemzetközi befolyásszerzése terén az úgynevezett kulturális terjeszkedés, vagyis a soft power útján történő pozitív imázsépítés. A teng-i fordulat után a vulgármarxizmussal való szakítás újból lehetővé tette Kína számára a kulturális forradalom idején pusztulásra ítélt konfuciánus kultúrkörökség föltámasztását, ami egy tökéletes, és turisztikailag is remekül hasznosítható egyedi arculatelemet adott az országnak. A világszerte gombamód szaporodó Konfucius-intézetek ennek a kultúrdiplomáciai missziónak a fölértékelődését mutatják. Ugyanakkor nem voltak mentesek a botrányoktól sem, mert néhány országban kémkedéssel vádolták meg a központokat, ami egyáltalán nem meglepő, hiszen nemcsak Kína használja hírszerzésre a diplomáciai misszióit. Amerikában a teljes fölszámolásukat is kilátásba helyezték, ami rávilágít az egyesült államokbeli már-már hisztérikus gyanakodásra Kína ellen. A Konfucius-intézetekben ugyanakkor Európában is megfigyelhető az intenzívebb hírszerzői tevékenység fölfutása és az egyetemi-akadémiai közeg, valamint az influencerújságírók kínai hírszerző ügynökök általi behálózási kitettsége is megnőtt az utóbbi években (Benner Th. - Gaspers J. - Ohlberg M. - Poggetti L. - Shi-Kupfer K., 2018). Ugyanígy nem csökken az ipari kémkedési aktivitás sem, bár sokszor ezt a vállalatfölvásárlások általi technológiatranszferrel igyekeznek pótolni a kínaiak, amely egy legálisabb és kevésbé botrányos formája a fejlett technológia megszerzésének. A járványhelyzet éppen ilyen fölvásárlási szituációk teremtésére alkalmas, amikor komoly értékvesztésen átesett nyugati technológiai cégek, vagy értékes brandeket birtokló vállalkozások a kínai tőketulajdonosok akvizíciós célpontjaivá válhatnak. Okulva a 2008-as pénzügyi válság hasonló negatív tapasztalataiból, az Európai Unió és az Egyesült Államok igyekszik egységes törvényi szabályozással védeni a kínai felvásárlástól azokat a technológiai és egyéb értékes cégeit, melyek részvényei és vállalati kötvényei átmenetileg elértéktelenedtek a koronavírus-járvány hatására és könnyü fölvásárlási prédává váltak. Ez azért is indokolt, mert Kína úgyszintén nem enged hozzáférést külföldi cégeknek saját, stratégiainak ítélt vállalataihoz, és így megvalósulhat a paritás elve.

A szun-ce-i álcázó manőverek, szintén a pozitív kép sugallására épülve, sokszor egyoldalú sikerpropagandaként mutatják be Kína társadalomépítési útját, elhallgatva az ország önkényuralmi berendezkedésének árnyoldalait. A koronavírus-járvány kapcsán fölmutatott „maszkdiplomácia” és a válságkezelés kínai kezelésének példátlan hatékonysága is az ország pozitív képét kívánták előtérbe helyezni a nyugati ilyen irányú „hatékonytalansággal” szemben, ami egy egyértelmü kommunikációs hadviselésnek a jele. A kínai nemzetközi kapcsolatokban azonban egyre inkább előtérbe kerülnek az agresszív hangvételre utaló jelek, az expanzív gondolkodásmód elötérbe kerülésével, amit Kína szomszédsági környezete fenyegetésként élhet meg. Hogy a kínai modell mennyire lesz vonzó az ország közelebbi vagy távolabbi környezetének, az azon múlhat, hogy az egészséges önbizalom vagy túlzott magabiztosság kerekedik fölül a geopolitikai erőpróbákban. Ha eluralkodik egy rossz értelemben vett hübrisz, a szun-ce-i óvatossággal szemben, az taszító hatású lehet, főként a kelet- és dél-ázsiai szomszédokra, melyek Amerikához menekülhetnek védelemért Kínával szemben. Lehetséges azonban, hogy a Kínaiak arra alapoznak, hogy a puszta növekedésükböl adódó roppant méretü kritikus tömeg, ami Kínát jellemzi majd, a józan belátás alapján már a Kínai „akolba” fogja terelni az államok többségét, melyek majd úgy pártolnak el a gyengülő Amerikától, hogy nem is kell az erőszakkal való meggyőzés eszközéhez nyúlni. A hadseregfejlesztés előtérbe helyezése a jövőben, a kolosszális méretüre duzzasztott haderő és a fölfuttatott nukleáris ütőerő olyan meggyőző erejü elrettentés lehet, a kínaiak reménye szerint, ami akár harci cselekmények nélküli területfoglalásra és befolyás-kiterjesztésre is lehetőséget adnak. Ez a krímihez hasonló, hibrid hadmüveletes területszerzést is lehetővé tenne, ahol nem is került sor harci összecsapásokra, vagy csak nagyon korlátozottan. (Itt azonban meg kell jegyeznünk, hogy Oroszországot nagymértékben segítette a Krím megszállásakor a félsziget Oroszországnak kedvező nemzetiségi szerkezete és az ebből eredő affinitások az agresszorral szemben). 
Ha a Csendes-óceánra Kína úgy tekint, mint egyfajta hatalmi-területi kiterjesztési terére, ugyanez érvényes bizonyos vonalak mentén az eurázsiai szárazföldre. Ennek a gazdasági birtokbavételét Kína az „Egy övezet, egy út” program meghirdetésével látja megvalósíthatónak (One Belt, one Road - OBOR-projekt). Itt talán még nehezebb az elörelépés, amit az is bizonyít, hogy a projekt 2013-as meghirdetése óta lényegi előrelépés nem történt. Az útvonal áthalad ugyanis délnyugat-ázsiai területeken és a régiót magát az arab tavasz által kiváltott belharcoktól még nem sikerült teljesen pacifikálni. Az útvonal második, északi ága ugyancsak bizonytalanabb, mert nagyrészt orosz területen halad végig, vagy a közép-ázsiai nagyrégión, ahol komolyan ütközhetnek a kínai és orosz befolyási érdekek. Kína és Oroszország mostani taktikai szövetsége ugyanakkor, első fázisban, mégis lehetővé teszi ennek az északi kereskedelmi, alternatív nyomvonalnak a megnyitását rövidtávon, az európai felvevő piacok felé. Az „új selyemútként” elhíresült infrastrukturális megaprojekt költségigénye hatalmas és elsősorban kínai gazdasági érdekeket szolgál, tehát a „kölcsönös előnyök” megvalósulása csak föltételes. Elsősorban kínai áruk exportját segíti elő az európai piacok irányába, az útvonal mentén pedig, a kínaiak által finanszírozott beruházásoknak köszönhetően, az elképzeléseknek megfelelően, kínai kliensállamok „,füzére” jönne létre. Az útvonalnak vannak vegyes, szárazföldi-tengeri szakaszai, mint a déli, Pakisztánon keresztülhaladó leágazás esetében. Ez az útvonal India megkerülését célozza és a Kasmíron keresztüli közös pakisztáni-indiai határkapcsolatot használja ki. Kína jelentős ráfordításokkal fölfejlesztette a pakisztáni gwadari kikötőt, Pakisztán délnyugati részén, ami fontos átrakodó kikötő a kínai áruk számára, melyek tovább haladnak Európa irányába. Erre a kerülőre azért volt szükség, hogy kritikus helyzetben az ellenséges India ne akadályozhassa ütőképes indiai-óceáni flottájával a kínai tranzit tengeri kereskedelmet.

Oroszországnak felemás helyzete van a két globális szuperhatalom, az Egyesült Államok és Kína közti versenyfutásban. Annak ellenére, hogy eurázsiai hatalomként definiálja magát, egyfajta átmeneti jelenségként a Kelet és Nyugat között, Oroszországot a kultúrája és keresztény vallása mégis inkább a Nyugathoz kötik. Birodalmi nosztalgiája, a jelenlegi vezetését sok esetben jellemző irracionalis kockázat-vállalás, amellyel nem hajlandó elfogadni immáron másodlagos szerepét a világrendben, mégis egy meggondolatlan és felelőtlen kalandorpolitika föszereplőjévé teszik a huszonegyedik század elején. Az állam vezetője, Vlagyimir Putyin elnök, egy, a kommunista rendszerben szocializálódott, KGB ügynök volt, ezért, mint gyakorló politikus is, szinte kizárólag a titkosszolgálati operatív felforgató tevékenység eszközei ismertek számára Oroszország külkapcsolatainak alakításában. Az Egyesült Államoknak nem tudja megbocsátani Zbigniew Brzezinski meglátása szerint - hogy békés eszközökkel, a hidegháborús zsákutcába szorítással megalázó vereséget mért a Szovjetunióra, és a szovjet birodalom összeomlásáról Putyin a huszadik század legnagyobb katasztrófájaként szól. Ez az anakronisztikus attitűd megakadályozza egy békés, konstruktív kapcsolatrendszer kialakítására a Nyugattal. Ehelyett például, internetes hadviseléssel, az orosz hackerek beavatkoznak az Egyesült Államok és az Európai Uniós tagállamok választási folyamataiba, fake news-ok, hamis hírek, lejárató kampányok terjesztésével, a választók elbizonytalanításával. Az orosz internetes zavaró képességek (hackelés) Sz. Bíró Zoltán szerint nem jobbak más országok ilyetén képességeinél a különbség az, hogy az oroszok ezeket a képességeket föként destruálásra használják és jellemzően felelőtlen aktorok.

Oroszország nemzetközi szerepvállalásai sem tanúskodnak túlzottan felelös magatartásról. Az Egyesült Államok által szintén felelőtlenül létrehozott közel-keleti hatalmi vákuumba és zürzavarba, amit az iraki invázió hozott magával, Oroszország úgy avatkozott be, hogy csapatokkal támogatja a szíriai polgárháborúban megrendült alavita rezsimet. Stratégiai érdekei is ezt diktálták, mivel az egyetlen meleg vizü, földközi-tengeri haditengerészeti orosz kikötő Szíriában van, Tartusban. Ez az orosz beavatkozás azonban a béke megteremtését nem hozta el, mintha csak egyetlen célja a még brutálisabb, esztelen pusztítás lenne, még nagyobb zürzavar keltése, az Európát is fenyegető migrációs nyomás fönntartásával, azáltal, hogy menekültek százezreit produkálja. Sz. Bíró Zoltán azt is megjegyzi, hogy ezekkel a szándékosan romboló, szubverzív tevékenységekkel Oroszország egy optikai csalódás által hatékonynak és 
erősnek, befolyásosnak próbálja föltüntetni magát, minthogy rombolni mindig sokkal könnyebb és kevesebb erőfeszítéssel jár, mint egy tartós egyensúlyi állapotot fölépíteni, ami víziót, valódi erőt és állhatatosságot igényel. Ugyancsak Sz. Bíró meglátása szerint Oroszország egyik fő problémája, hogy a nagyhatalmi aspirációkat mindig előtérbe helyezi népe boldogságával és boldogulásával szemben, $\mathrm{s}$ az így elszenvedett sorozatos kudarcok egy vég nélküli frusztrációs spirált generálnak az oroszokban (Sz. Bíró, 2019). Mindezeket a negatív folyamatokat csak felerősíti egy rendkívül hangos, erőszakos és agresszívan nyomuló orosz sikerpropaganda, melynek elsődleges csatornája szintén az internetes közösségi szájtok, s melynek az a célja, hogy tekintélyt vívjon ki Oroszország hatalmi erejének és Putyin elnök látszólagos providenciális képességeinek.

Oroszország gazdasági sebezhetősége továbbra is abból ered, hogy gazdasági összeteljesítménye mindössze Spanyolország szintjén áll, viszont mindez egy Spanyolországnál három és félszer nagyobb népességszám mellett érvényesül, messze lemaradva Amerika és Kína gazdasági mutatószámaitól. Ez arra elegendő, hogy egy modern fegyverekkel ellátott, békeidőben 750 ezres létszámú hadsereget fönntartson és az Egyesült Államokkal lényegében paritásban álló, a világon a második helyre sorolható atomarzenált mondhasson magáénak. Oroszország a világ technológiai innovációinak mindössze $0,25 \%$-át adja csupán és gazdasága alapvetően nem képes versenyképes, magas technológiai hozzáadott értéket termelni, a hadiipar kivételével. Bevételeiben nagy fluktuációt jelent a monoindusztriális jellegü szénhidrogén- és érckivitel. A kiterebélyesedő világjárvány okán elmélyülő gazdasági válság, a szénhidrogének iránti keresletet is összeomlasztja, nem beszélve a palaolaj- és palagázforradalom, valamint a megújuló energiák támasztotta konkurenciáról, mely szintén az orosz energiahordozó-export ellen dolgozik.

Az orosz demográfiai helyzet katasztrofális, a népmozgalmi mutatók gyorsuló természetes fogyást vetítenek elöre, úgy, hogy az alacsony életszínvonal miatt az ország nem egy vonzó bevándorlási célpont. A férfiak várható élettartama rekordalacsony a közepesen fejlett országok közt (65 év), elsősorban a nem megfelelő színvonalú egészségügyi ellátás és a társadalmi devianciák (elsősorban alkoholizmus) széles körü elterjedése miatt.

A gazdasági növekedés a 2008-as gazdasági válságot követően megtorpant, amit súlyosbítottak az amerikai és európai uniós szankciók a Krím-félsziget orosz elcsatolását követően (2014 óta vannak érvényben). A kétezres években viszont a rohamtempóban növekvő olaj- és gázárak gyorsuló fejlődési pályára állították Oroszországot, konszolidálódó gazdasággal, mely ezekben az években lépett csak túl a kilencvenes évek transzformációs válságának megrázkódtatásain. Ebben az időszakban, a palaolaj- és palagáz forradalmat megelőzően, Oroszország sikeresebben alkalmazhatta a szénhidrogén-exportját zsarolási eszközként a töle függő helyzetben lévő FÁK (Független Államok Közössége) és az európai országokkal szemben. Mióta a nyugati szankciókkal és az Ukrajnát elkerülő csővezetékek kiépítésének halasztódásával számtalan kérdőjel vetődött föl az Európa felé irányuló orosz gázexport biztonságát illetően, azóta Oroszország a távol-keleti (elsősorban Kína felé irányuló) gázszállítások felé orientálja újra a kivitelét. Ilyen értelemben megkezdte az ebbe az irányba vivő gézvezetékek kiépítését, így csökkentve exportfüggőségét az európai piacok felé, diverzifikálva és biztonságosabbá téve a keresletet.

Az orosz expanziós törekvések elsősorban a volt szovjet utódállamok szuverenitására jelenthetnek veszélyt (kiemelten Ukrajnára és Belaruszra). Oroszország kezdeményezése 2014ben kieszközölte az Eurázsiai Gazdasági Unióban való részvételt néhány volt szovjet utódállam esetében (Oroszország, Kazahsztán, Belarusz, Örményország, Kirgizisztán), mellyel saját hatalmi súlya körül az Európai Uniót kívánta ellenpontozni egy jóval kevésbé elmélyültebb politikaigazdasági integrációban. Ebben a kontextusban igyekszik megakadályozni, hogy a volt szovjet közép-ázsiai köztársaságok önállóan léphessenek föl olaj- és földgázexportőrként a világpiacon, annak érdekében, hogy ellenörzést gyakorolhasson a térség roppant szénhidrogén-gazdagsága felett és megőrizze saját szénhidrogéntermelésének a kedvező export-pozícióit a világpiacon. Ilyen értelemben, igyekszik a térség kulcsállamát, Azerbajdzsánt, a kezében tartani, minthogy csak ezen keresztül valósulhat meg a nagytérség szénhidrogén exportja nyugati irányba. 
Oroszország terveit mindazonáltal némileg keresztülhúzta a transzeurázsiai gázvezeték Kína felé való kiépítése, amely lehetővé teszi a türkmén fölgáz közvetlen eljuttatását Kínába, orosz kontrol vagy közvetítés nélkül. Ez a tényező is közre játszhat a jövőben egy mélyülő orosz-kínai ellentét fölbukkanásában, a Közép-Ázsia fölötti befolyást illetően. Ezen okból is, valamint a Szibériára nehezedő Kínai demográfiai és gazdasági nyomás okán beszélhetünk csupán egy taktikai, és a jelenben fönnálló orosz-kínai hallgatólagos szövetségről, melynek a tartóssága iránt kétségek merülnek föl. Az Egyesült Államok számára a közép-ázsiai térség a terror-ellenes háború idején bírt jelentőséggel a katonai támaszpontok fönntartása miatt. Azóta azonban Amerika innen kivonult és egy kínaiaktól adoptált, úgymond importált szun-ce-i bölcsességgel, távolról szemlélve hagyja, hogy ellenfelei „összekapjanak” ezen a tőle távol levő, energiahordozókban való mesés gazdagsága miatt viszont egyedülállóan fontos régión. Ha Kína az endogén fejlődésre akarja alapozni a jövőbeni növekedését, az oly mértékben megnöveli a belső fajlagos fogyasztást, hogy a jelenleginél is sokkal nagyobb mértékü lesz a kínai nyersanyagigény. Ez fokozott keresletben materializálódik majd a Kína számára könnyebben elérhető közép-ázsiai páratlan szénhidrogén-vagyon iránt és Szibéria nyerstermék-készleteire is ki fog terjedni. Mindez magában kódol egy jövőbeni orosz-kínai konfrontációt. Ha korábban Európa szintjén igaz volt az a szlogen, hogy Németország és Oroszország természetes szövetségesek, úgy Eurázsia szintjén is igaz, hogy Oroszország és Kína természetes ellenségek, legalábbis a jövőben könnyüszerrel azzá válhatnak.

Annak érdekében, hogy szövetségi rendszeren keresztül is kiterjessze befolyását a volt szovjet térség fölött, Oroszország kezdeményezésére 1992-ben létrejött a Kollektív Biztonsági Szerződés Szervezete (Collective Security Treaty Organization), amit kollokviálisan a kelet NATO-jaként is emlegetnek. Ez a szervezet jelenleg hat tagállamból áll, mindegyikük az egykori szovjet térségből származik: Oroszország, Kazahsztán, Kirgizisztán, Tádzsikisztán, Belarusz és Örményország. Ez a szervezet sokkal formálisabban és hatékonytalanabbul müködik, mint a NATO és lényegében az orosz nagyhatalmi nosztalgia egyik „félkészterméke”. Ezt alátámasztja a 2020 novemberében örmény kapitulációval lezáruló örmény-azeri háború, melyet HegyiKarabahért vívtak. Az örmények az elszenvedett katonai vereségért joggal éreznek csalódottságot a nyugattal szemben, de ez semmiképp sem hasonlítható össze azzal a dühvel szemben, amit az úgymond szövetséges Oroszországgal szemben éreznek, mely szövetségesi kötelezettségeinek nem téve eleget, nem tudta szavatolni az örmény érdekeket. Ez annak ellenére is szövetségesi bizalomvesztést okozhat Oroszországgal szemben bármely szövetségese részéröl, hogy a konkrét karabahi konfliktus esetében egy örmény többségü, azonban formálisan mégiscsak Azerbajdzsánhoz tartozó területről beszélünk. Ez a konfliktus ugyanakkor megmutatta, hogy a nyugati közöny esetében is, Oroszország már nem képes egykori befolyási övezetében egyedül békét teremteni, hiszen itt a rendcsinálásban messzemenőkig figyelembe kellett vennie az Azerbajdzsánnal szövetséges Törökország érdekeit is.

Mind Kína, mind Oroszország érdekelt a nyugati világ oszlopos képviselője, az Európai Unió gyöngítésében és bomlasztásában, amivel az Egyesült Államok fontos „hátországát” is alááshatják. Ugyanez vonatkozik a nyugati világ katonai szövetségére, a transzatlanti együttmüködés bázisát képező NATO-ra, melyben különösen Oroszország lát alaptalanul közvetlen fenyegetést. Bár Donald Trump 2016-os hivatalba lépésével lazultak a transzatlanti kapcsolatok és az e tekintetben szüklátókörünek mutatkozó amerikai külpolitika elkezdte mindinkább úgy kezelni az Európai Uniót, mint egy gazdasági riválist (különösképp igaz volt ez az amerikai hozzáállás az EU zászlóshajójára, Németországra vonatkozóan). Mindazonáltal a trump-i szigor végül is Oroszországnak kedvezőtlen fordulatot hozott a NATO-ban, ugyanis az amerikai részvétel csökkentésének belengetése a kollektív biztonságban energikus védelmi-kiadás bővülést hozott a NATO-tagok mindegyikében, ami egyáltalán nincs Oroszország ínyére. Az orosz kiterjesztett expanziós és birodalmi-rehabilitációs célok még a korábbi „közeli külföldként” számon tartott befolyási övezet, Közép-Európa alávetését sem zárnák ki egy esetlegesen fölbomló EU és NATO romjain. Kína is jobb szeretne számára előnyös kereskedelmi föltételeket diktálni, vagy közvetlen politikai befolyást gyakorolni fölaprózott, gyenge és számára kiszolgáltatott európai államokra, mint egy egységes, sikeresebb érdekérvényesítő erővel bíró EU-val 
kompromisszumokat keresni. Az orosz imperializmus a jól ismert internetes álhíres manipulációk mellett pénzügyi támogatásban részesít európai establishment-ellenes szélsőséges pártokat, a politikai extrémizmus mindkét palettáján, ami a politikai szubverzió egyik hatékony eszközének bizonyul. Ez sem előzmények nélküli, ugyanis a Szovjetunió Nyugat-Európa kommunista pártjait és marxista terrorszervezeteit támogatta, és ugyanezen a mintán tovább haladva Oroszország mára az európai szélsőjobboldali pártoknak nyújt közvetlen anyagi támogatást. Jelenleg Európában a német nagytőke a legfogékonyabb az orosz kapcsolatok üzleti kiaknázására, és a német politikai elitet is ebbe az irányba igyekszik terelni (lásd többek közt az Északi Áramlat gázvezeték bővítési tervét), ami éles kritikákat vált ki Németországgal szemben, különösen Washington oldaláról.

Összességében véve, Oroszország tagja lehetne egy - Brzezinski megfogalmazásában „nagyobb és életerősebb Nyugatnak”. A jelenlegi, bebetonozott hatalmú elnöke mellett azonban, akinek föleg Amerikával szembeni sérelmei kvázi lehetetlenné teszik egy reálpolitikai kiegyezés megvalósulását, valamint az európai térfelen a NATO-val való közvetlen rivalizálás inkább taszítja Oroszországot egy Kínával létrehozandó, egyelőre informális szövetség felé. Ugyanakkor ez a kvázi szövetség gyenge lábakon áll, mert az oroszok számára ez egyértelműen alárendelt szerepet jelent és állandóan kísérteni fogja a Szibéria és Közép-Ázsia fölötti kínai-orosz nagyhatalmi viszály lehetősége. Ugyanakkor egyelőre Kína irányából is érzékelhető egyfajta tartózkodás az orosz szövetség fenntartások nélküli befogadása irányába.

Egy Kína köré szerveződő, egyelöre informális szövetségi rendszer legújabb lehetséges tagja Irán lehet, miután az iráni atomegyezmény Trump-kormányzat általi egyoldalú fölrúgását követően Irán újból súlyos szankcióknak lett kitéve. 2020 legelején az Egyesült Államok és Irán a háború szélére sodródott, miután az amerikai hadsereg egy dróntámadás által likvidálta az Iráni forradalmi gárda különleges erőinek parancsnokát, és Irán közel-keleti háborús tervezésének fő stratégáját, Kászem Szolejmánit. A 2020-as koronavírus-járvány kiélezte Kína és az Egyesült Államok közti propagandaháborút, valamint Irán új nagyhatalmi patrónus iránti igénye is összehozhatta Kínát Iránnal. A kiszivárgott terveztek szerint Kína egy 400 milliárd dolláros gigatámogatással sietne a pénzügyi szankciók által szorongatott Irán segítségére, amibe belefoglalná a valószínűleg az „Új Selyemút” projektben már szereplő infrastruktúra beruházások zömét is. Cserébe Kína kőolajat és további befolyást kapna. A tervezet már önmagában is hatalmas kihívás Amerikával szemben, és hanyatló hatalmának kifejező szimptómája, minthogy nem tudja megakadályozni rivális hatalmak provokatív föllépését az amerikai stratégiai tervekkel szemben. Ez a kihívás, ha megvalósul, egyértelmüen bizonyítja, hogy Kína hajlandó egyre inkább frontális konfliktusok fölvállalásába és potenciális Amerika-ellenes kliensállam-rendszer kiépítésébe, vállalva ennek pénzelését is. Erre a szuverén mozgástere és a finanszírozáshoz szükséges anyagi háttere is megvan. Amerika természetesen gőzerővel dolgozik egy regionális ellenpólus szövetségi rendszer létrehozásán - ennek képezi a részét az öböl-menti arab államok és Izrael újfajta, korábban elképzelhetetlen taktikai szövetsége az Iráni militáns fenyegetés ellentételezésére. Mindezek a folyamatok, az iráni atomprogram föléledésével egy rendkívül veszélyes gyúanyagot eredményeznek a térségben, mely lángba boríthatja az egész Közel-Keletet egy eddig példátlanul pusztító proxy-háborúban.

Végül a Kína oldalán jelenleg „összeálló” középhatalmak oldaláról az atomhatalomként is funkcionáló Pakisztánról érdemes pár szót említeni. A deklaráltan iszlám köztársaságként müködő Pakisztán Iránnál jóval mérsékeltebb politikát folytat, tartózkodva a vallási szélsőségektől. Fő regionális riválisa India, amely közös akolba terelte Kínával. Pakisztán a Kínával való kereskedelmi együttmüködés és technológia-transzfer haszonélvezője. Indiával, a közös nukleáris zsarolás teremtette kvázi stabilitás körülményei közepette, az 1999-ben vívott legutolsó kasmíri háborút követően Pakisztán egy relatív zökkenőmentes egymás mellett élés feltételeit alakította ki. Az afganisztáni tálib-ellenes háború idején az Egyesült Államok „kényszer-szövetségeseként” - ímmel-ámmal megadta Amerikának a szükséges logisztikai támogatást, miközben 2011-es likvidálásáig hagyta, hogy Oszama Bin Laden menedéket találjon az országban. A végleges afganisztáni amerikai kivonulást követően igyekszik Iránnal és Indiával versenyt futva minél jobban pozícionálni magát Afganisztánban, hogy, lehetőség szerint, a vele 
szövetséges törzsek kontrolálják majd itt a föhatalmat. Pakisztán ugyanakkor a nukleáris proliferáció terén képez egy bizonytalansági tényezőt, ugyanis szerep lehet az atomtechnológia Irán felé történő átjátszásának.

Részösszegzésként megállapítható, hogy Kína megállíthatatlan menetelése a világhatalom felé egy új minőség megjelenését eredményezheti a világpolitikában, nevezetesen a méretbeli, történelmileg példátlan erőkoncentráción alapuló hiperhatalmi kategória színrelépését jelentheti. Ez annyit jelent, hogy riválisainak a korábbiaknál nagyobb számban kell szövetkezniük ellene, hogy hatékony ellenállást, illetve föltartóztatást legyenek képesek fölmutatni. Ez a méret annyira riasztó lehet, hogy az eddigi reakciók is az ellenségeskedések félelem-alapú eszkalációjával egy új hidegháborút válthatnak ki a huszonegyedik század első felétől.

\section{Az Egyesült Államok változó szerepe - a jelenlegi világrend állagőrzése}

A fiatal demokráciaként a nemzetközi rendbe a 19. század folyamán betagozódó Egyesült Államok a 19. és 20. század fordulóján a mai kínaihoz hasonló szédületes ipari fejlődés eredményeképpen vált naggyá. Ugyancsak Kínához hasonlóan, a 19. századi belső szerves növekedés és „érés” időszakában kevésbé vállalt szerepet a nemzetközi porondon. Az izolacionista fejlődés ekkor egyfajta amerikai külpolitikai hagyománnyá vált, melynek káros reminiszcenciái napjainkban is éledeznek, párhuzamosan azzal, ahogy a zenitjére érö világhatalom a kifáradás jeleit mutatja.

Szokás mondani, hogy a 20. század Amerika évszázada volt, mert az Egyesült Államok végig a legnagyobb nemzetgazdasággal rendelkezett az adott korszakban és a két világháború igazi győzteseként került ki a katasztrofális hatású világégésekből. A második világháborút követően, mikor Európa romokban hevert, az Egyesült Államok ipari termelése meghaladta a világtermelés 55 százalékát is (Probáld, 2004, p. 31). A két világháború nem okozott közvetlen rombolást az Egyesült Államokban - a veszteségek költségekben és emberveszteségekben mérhetők, de Amerika szerencséjére a termelökapacitásai ekkor érintetlenek maradtak. A két háború utáni világrend kiépítésébe megpróbált aktívan beleavatkozni a tartós békét szavatoló nemzetközi intézményrendszer kiépítésével, ám ez csak a második világháborút követően sikerült. Az első világháború, bár az Egyesült Államok beavatkozása meghatározta annak kimenetelét, mégsem végzödött teljes amerikai sikerrel, abban az értelemben, hogy a béketárgyalásokon nem sikerült maradéktalanul érvényesíteni a végtelenül idealista wilsoni elveket a népek önrendelkezéséröl. Egyedüli sikerként könyvelhető el a Népszövetség létrehozása, mely, bár hatékonytalannak bizonyult, mégis pozitív elöképe lett a második világháború után jóval eredményesebben föllépő Egyesült Nemzetek Szervezetének. Ugyancsak sikerként számolhatunk be ekkor a Wilson által oly gyakran kárhoztatott titkos diplomácia háttérbe húzódásáról. Mindazonáltal Wilson látva az európai győztes hatalmak nyerészkedő, bosszúszomjas telhetetlenségét a versailles-i rablóbéke területi és jóvátételi osztozkodásainál, rövid időn belül hátat fordított a békekonferenciának és nem ratifikáltatta a békeszerződést. Sokakkal ellentétben Wilson jól érzékelte azt, hogy az úgynevezett békeszerződés egy rövid időn belül föllángoló, még véresebb viszálykodás magvait veti el, egy stabil, békére épülő világrend megalkotása helyett.

Jellemzően az ,amerikai álomba”, az amerikai modell vezérelte társadalomszerkezetbe vetett hit akkor szokott alapjaiban megrendülni, mikor az Egyesült Államok területéről kiindul egy olyan pénzügyi válság, mely maga alá temeti a világgazdaságot - ez történ 1929-ben és ez ismétlődött meg 2008-ban is. Mindkettő nyomában világszerte fölerősödtek a politikai szélsőségek, bár a korábbi tapasztalatok alapján ezt a válságot 2008-ban sikeresebben kezelni tudták és kordában sikerült tartani a kilengéseket.

Sajnos a „válságkezelés” a 20. század első felében, paradox módon, részben a második világháborúval valósult meg, ugyanis a mély recesszióra igazán csak a háborús konjunktúra jelentette akkor az igazán hatékony megoldást, legfőképp a háborús károkat nem szenvedő Amerikában. Ugyanezeket az áldozatokat azonban napjainkban nem áll módunkban fölvállalni, az ilyen extrém helyzeteket mindenképp el kell kerülni. 
A második világháborút követően az Egyesült Államok és az általa megszervezett nyugati világ páratlan sikeres konjunktúrán ment keresztül, mely megteremtette a jóléti állam történelmileg példátlan életszínvonalát és ehhez kapcsolódó technológiai- és kényelmi színvonalát. A fegyelmezett tudatossággal alkalmazott föltartóztatás (containment), visszaszorítás (roll-back) politikájával, a nukleáris arzenál biztosította kölcsönös megsemmisítés elvével (Mutual Assured Destroying) Amerika elérte, hogy a világkommunizmus ne terjeszkedhessen a kezdetben vázolt dominóelv képlete szerint. Amerika átküzdötte magát, felemás eredményekkel, a hidegháború forró pontjain, mint a koreai háború, a berlini blokád, a kubai rakétaválság, a vietnámi háború és megnyerte a Szovjetunióval szemben az inkább imázs-értékü ürversenyt. Végül, egyre bővülő gazdasági, pénzügyi, termelékenységi és főleg technológiai előnyét kihasználva, négy és fél évtized hidegháborúja után az Egyesült Államok megroppantotta a szovjet rendszer gerincét. A szocialista országok rendszerváltását, valamint a Szovjetunió összeomlását követően Amerika egyedüli szuperhatalom maradt a világ színpadán.

Az amerikai geopolitikai filozófiában két irányzat különíthető el, melyek keveréke és okosan titrált alkalmazása jellemzi az amerikai külpolitika alkalmazott formáit. A két tárgyalási mód tehát ebben a kontextusban nem antagonisztikus, annak ellenére, hogy látszólag egymás ellen feszülő bináris ellentétpárról beszélhetünk. Az amerikai realista irányzat „politikai iskolájának” alapító példaképe a 20. század elején hivatalban lévő Theodor Roosevelt elnök volt, aki az amerikai nemzeti és hatalmi érdekek mentén alakította az ország nemzetközi kapcsolatait, tágabb keretben is. A tágabb keret azt jelentette, hogy nemcsak az Egyesült Államok térbeli tőszomszédságában konszolidálta a spanyol-amerikai háború (1898) utáni Amerikának kedvező befolyás-gyarapodást, hanem a távol-keleti új status quo fölállításában is aktív közvetítő szerepet vállalt (példa erre az orosz-japán háborút lezáró portsmouthi békeegyezmény 1905-ben). Woodrow Wilson testesíti meg az ellentétes, idealista oldalt a föntebb vázolt, első világháború körüli ténykedései miatt (Kissinger, 2013, pp. 25-48). Ez az értékvezérelt, a szabadságeszményt, az önrendelkezést és emberi jogokat előtérbe helyező politikai attitüd azonban Wilson esetében sem jelentkezett vegytisztán. Az első világháború esetleges német győzelme alapjában kérdőjelezhette volna meg az addig Nagy-Britanniának nyújtott, és brit közvetítéssel által az Antantnak is utalt tetemes mennyiségü háborús hitelek visszafizetését. Ez lehet az oka annak, hogy számos alternatív interpretáció alapján, az Egyesült Államok az értékelvű szólamok máza alatt az első világháborúba azért is lépett be, mert „futott a pénze után”. Mindent egybevetve, Theodor Roosevelt és Woodrow Wilson óta az amerikai külpolitika sajátja és relatív sikereinek titka, hogy e két irányzat értelmes elegye vezetett oda, hogy Amerika a világtörténelem, rövid ideig, a hidegháború lezárását követően, egyetlen szuperhatalmaként lehetett jelen a világrend porondján, és a hatalmi kizárólagosságnak ezt a teljesítményét, Brzezinski szerint, senki nem tudja majd a jövőben megismételni.

A külpolitikai magatartás ezen elözményeinek ismeretében fogalmat alkothatunk arról, milyen tradicionális faktorok mentén szerveződik az amerikai világszemlélet és milyen típusos válaszokat hajlamos megfogalmazni különböző külkapcsolati impulzusokra.

Jelen tanulmány kiinduló tézisei közt szerepel az a Zbigniew Brzezinskitől kölcsönzött álláspont, hogy a jövőbeni kétpólusosság Kína fölemelkedése révén azt a világtörténelmileg egyedülálló állapotot váltja föl, amelyben egy állam, jelesül az Egyesült Államok, évtizedekig egyetlen szuperhatalomkét volt jelen a Szovjetunió és a szocialista világrend összeomlását követően. Brzezinski szerint a jövőben nem ismétlödik meg egy ilyen helyzet, mert az Egyesült Államok és az általa gründolt szövetségi rendszer, a relatív amerikai hanyatlás ellenére sem fog oly mértékben meggyöngülni, hogy a helyébe a jövőben egyetlen hegemón léphessen csupán.

Az Egyesült Államok által küldetéses módon vallott értékek, melyek az amerikai legitimitás-tudat bázisát képezik, egyoldalúan a nyugati hatalmak által propagált normarendszerként vannak jelen pillanatnyilag is a világpolitikában. Ez az oka annak, hogy egyre többen megkérdőjelezik ezt, hiszen nem vettek alkotóan részt e normarendszer megkonstruálásában. Ezt az eddig domináns normarendszert, mellyel a polgári demokráciák önmaguk szabadságeszményeit határozzák meg egyre inkább megkérdőjelezi a Kína köré 
összpontosuló ellentétes nézetrendszert valló hatalmi pólus. Ez a pólus lesz az Amerikai egyeduralom kihívója, mely a determinációként bekövetkező amerikai befolyás-csökkenés stációit ki fogják használni hatóerejük békés vagy agresszív terjesztése érdekében. A világpolitika különböző színterein vannak olyan kritikus helyzetben lévő ütközőállamok, melyek kiemelt sebezhetőségük által különösképp ki lesznek téve az ellenpóluson az orosz vagy kínai hatalmi nyomásnak, mihelyt ezek a terjeszkedő szándékú államok az amerikai hegemónia különböző stádiumú hanyatlását érzékelni vélik. Brzezinski szerint ezek közül a sebezhető államok közül Georgia, Belarusz és Ukrajna az orosz expanzionizmus áldozatai lehetnek, míg Tajvan és DélKorea a kínai előre nyomulás lehetséges célpontjai. Ugyanakkor Afganisztán, Izrael és Pakisztán is megmaradnak kritikus területeknek, melyek a radikális iszlám terjedéséből adódóan veszélyeztetett területek (Brzezinski, 2013, pp. 133-150). A hidegháborút követően ezekben a térségekben az amerikai „,csendőri” jellegü katonai beavatkozás, vagy pusztán a katonai jelenlét, ötvözve a gazdasági, technikai, logisztikai támogatással, amit ezek a kritikus helyzetű államok kaptak, mind hozzájárult egy viszonylagos geopolitikai stabilitás fönntartásához. Ugyanis a hidegháború utáni amerikai hegemón hatalmi magatartást összes hibája ellenére fő vonalaiban a felelős föllépés jellemezte, amely felelősség a mértékletesség vonatkozásában nem biztos, hogy érvényesülni fog az Amerika utáni világban. Kína eddigi „kivárásos”, erőforrásait kímélő magatartása olyan kvázi-passzivitást eredményezett, amelyből nem lehet pontosan megjósolni egyfajta jövőbeni „pax sinica”-nak a konstellációját. Az orosz frusztrációk a hatalmi „másodhegedűs” szerepkörből adódóan arra ösztönzik Oroszországot, hogy külpolitikai hagyományainak megfelelően is agresszíven és elnyomóan lépjen föl az érdekszférájában lévő kisebb országokkal szemben. Mindezt Oroszország, az amerikai szupremácia gyengülésével arányosan, egyre magabiztosabban és növekvő agresszivitással tenné meg. Mindezek a tényezők veszélybe sodorják a második világháború során teret nyerő és a nemzetközi biztonságot elősegítő institucionalista multilateralizmust, helyette elönyben részesítve a bilaterális viszonyrendszereket, ami az erősebb fél „ököljog” alapján elért győzelmével zárul minden esetben és kikezdi a nemzeti szuverenitáseszményt. Ennek megfelelően könnyen valóra válhat a Brzezinski által plasztikusan megfogalmazott makáber-szcenárió, melynek értelmében a 2025 utáni világrend sem amerikai, sem kínai nem lesz, hanem kaotikus, melyben a biztonság „cseppfolyóssá” válik (Brzezinski, 2013, pp. 113-173).

Ugyanakkor a hidegháború utáni „világ csendőr” szerepet az Egyesült Államoknak sem sikerült mindig igazi felelősséggel eljátszania. Az első öböl háború és a délszláv válságba való beavatkozás még legitimnek mondható a mások szuverenitásának védelme és a kisebbségvédelem keretében. Ugyanez elmondható a „terrorizmus elleni harc” afganisztáni hadszínteréről, ahol a 2001-es new york-i terrortámadások értelmi szerzője, az Al-Kaida ellen folyt a katonai föllépés az önvédelem jegyében. De ugyanezeket már nem mondhatjuk el a hamis vádakkal megalapozott (tömegpusztító fegyverek Irak általi birtoklása és gyártása) második öböl háborúról, ami az indokolatlan iraki inváziót hozta magával. Ez egy olyan rekordhosszúságú ideig tartó, költséges és a megtámadott ország népességének fölösleges és mérhetetlen szenvedéseket okozó, nagyszámú áldozatokkal járó hadmüvelet volt, amit csak a destrukció és a fölforgatás fogalmaival tudunk leírni. A háborúban kifáradt amerikai haderő, a vietnámi háborúhoz hasonlóan egy olyan hadmüveletbe ragadt bele, amit a hazai közvélemény sem támogatott már.

Barack Obama elnöksége idején megkezdődött a külföldi amerikai szerepvállalás általános visszafogása és a figyelem átterelődése a Csendes-óceán térségére, a felnövő új kínai vetélytárs szemmel tartása érdekében (Pivot to Asia). Ez egy fokozatosan kiürített Irakot és Afganisztánt hagyott maga után, ahol az összességében katonai kudarcot magával hozó kalandot követően nemhogy a térség végtelenül illuzórikus demokratizálása nem történt meg, de olyan hatalmi ür keletkezett, amit a korábbiaknál még agresszívebb, és anarchikusabb terrorista rezsimek foglaltak el. Ennek következtében elmondható, hogy Amerika a legutóbbi közel-keleti katonai akciója következtében hozzájárult az instabilitás fokozásához és a „failed state” kategóriájú államok (kudarcállamok) számának oktalan szaporításához. 
Amerika iraki kalandorpolitikája és a 2008-as pénzügyi válság együttes hatása gyökeresen hozzájárult az Egyesült Államok drasztikus presztízs-veszteségéhez még az olyan államok körében is, akik szövetségesei voltak Amerikának, vagy legalábbis elismerték az amerikai társadalmi berendezkedési modellt követendő példaként. Az ellenfelek oldaláról pedig könnyü támadási felületet biztosítottak ezek a súlyos hibák, melyek hozzá is járultak az amerikai hatalmi szupremácia gyorsabb eróziójához. Különösen Kína volt aktív az amerikai pénzügyi rendszer kritikájában, a deregulációs, neoliberális pénzügyi innovációk és kapzsi nyerészkedési sémák egyáltalán nem indokolatlan, vitriolos bírálatában.

Nem tett jót Amerika imázsának az ország gyorsan degradálódó infrastruktúrája, mely az amerikai hanyatlás szimbólumává vált, különösképp kontrasztba állítva Kína rendkívül imponáló és nagyszabású infrastruktúra-projektjeivel. Amerika romló színvonalú közoktatása, az esélyegyenlőség hiánya az oktatási rendszerben szintén évek óta éles kritikák tárgya. Az elégtelen közoktatási teljesítmény, különösen a földrajzi és történelmi ismeretek alacsony szintje az amerikai érettségiző fiatalok és a felnőtt lakosság körében alááshatja egy nemzet önképét, identitását, tájékozódását térben és időben, ami egy szuperhatalom polgárainak létszükséglet lenne ahhoz, hogy államuk sikeresen őrizze meg vezető státusát a világban. Ez a tudatlanság Brzezinski véleménye szerint növeli az amerikai lakosság kitettségét a manicheista demagógiának, a populista uszításnak, a politikai valóság érdekcsoportok által fabrikált szélsőséges leegyszerüsítésének (Brzezinski, 2013, p. 84).

A globális pénzügyi válságot követően az Egyesült Államokban fölerősödtek azok a félelmek, hogy a Kínai növekedés egyre közvetlenebb kihívást jelent az amerikai pozíciókra és a kínai bővülés fékezését helyezték előtérbe, a közel-keleti hadszíntér lépésről-lépésre való föladásával párhuzamosan. Erre az Obama rezsim az amerikai gazdasági befolyás kiterjesztését látta célravezetőnek az úgynevezett Transz-csendes-óceáni Partnerség (Transpacific Partnership Agreement) keretében, ami egy olyan vámegyezményt jelentett, mely gyürüszerüen felölelte a Csendes-óceán körül az összes fontosabb kereskedő nemzetet, amiből azonban kimaradt Kína. Az amerikaiaknak sikerült tehát egy olyan koalíciós gazdasági erőteret szervezniük a kínaiak ellenében, mely elismerte a nagytérségben az amerikai elsőbbséget, sőt az egyezmény partnerországai is fönntartásokkal viseltettek a kínai gazdasági és hatalmi elöre nyomulással kapcsolatban, esetenként amerikai gazdasági védőernyőt remélve ezzel szemben. Ekkor az amerikai félelmek Kína növekedésével kapcsolatban kísértetiesen kezdtek hasonlítani arra az enyhén hisztérikus reakcióra, amit az Egyesült Államok a nyolcvanas években produkált az egyre fenyegetőbben magas kereskedelmi többletet produkáló Japánnal szemben.

E nagy mügonddal megalkotott gazdasági bekerítő akciót rombolta le rekord gyorsasággal a 2017-től hivatalba lépö új amerikai elnök, Donald Trump, miután kiléptette Amerikát az egyezményből, utat nyitva az esetleges kínai befolyási-övezet építésnek. Ugyanakkor a Trump adminisztráció kétségessé tette a Transzatlanti Kereskedelmi és Beruházási Partnerség (Transatlantic Trade and Investment Partnership) tető alá hozását az Európai Unióval és gyakran hangoztatja az Észak-amerikai Szabadkereskedelmi Egyezmény (North American Free Trade Agreement) újratárgyalására vonatkozó igényeit.

Mindezek a lépések a Trump adminisztrációra jellemző hektikus döntéshozatal eredményei, amelyek hajlamosak csupán a rövid távú amerikai érdekeket figyelembe venni, a kereskedelmi deficit csökkentésére és a hazai munkahelyvédelemre vonatkozóan. Kétségtelen, hogy a fölgyorsuló globalizáció, a liberalizálódó tőkekiáramlás és a heves bérverseny a globális munkaerőpiacon amerikai állások millióit szüntették meg vagy sodorták veszélybe az elmúlt évtizedekben és okoztak látványos dezindusztrializációt. A megrendült egzisztenciájú, képzetlenebb „kékgalléros” munkavállalói kör (de nem csak ők, hanem egyéb társadalmi csoportok is) egzisztenciája vált bizonytalanná és fenyegeti őket a deklasszálódás réme. Öket a legkönnyebb megszólítani demagóg és harcias ígéretekkel, melyek a sokasodó társadalmi bajokat jobbára exogén okokkal magyarázzák, és gyors megoldásokat ígérnek a szaporodó prekariátus számára. Az Egyesült Államok belső hanyatlásának legbiztosabb látlelete az amerikai álom azon szegmensének összeomlása, mely a háború utáni hosszú évtizedek prosperitása után mára 
kitermelt egy olyan generációt, akik a szüleikkel összehasonlításban relatíve alacsonyabb jövedelmekre számíthatnak a jövőben, magyarán intergenerációs deklasszálódásról beszélhetünk.

Mindezekkel az elhamarkodottságot és átgondolatlanságot sugalmazó, „csapkodó” amerikai intézkedésekkel szemben áll egy sztoikus és minden szempontból hosszútávra tervező kínai kiszámítottság, a fontolva haladó kereskedelmi-gazdasági pozíciószerzés tekintetében. Az Egyesült Államok által „elengedett” Csendes-óceáni Partnerségben a vezető szerepet könnyüszerrel a konfuciánus bölcsességgel kiváró Kína veheti át, stratégiai előnyre téve szert a rövid távú szempontokat fölnagyító amerikai „,vaksággal” szemben. A Csendes-óceáni térség amely felé Amerika úgy fordította a tekintetét a 2010-es években, hogy relatív árnyékzónában hagyta a hagyományos transzatlanti kapcsolatokat - ezáltal az óvatlan „tüzoltó-akciók” eredményeképpen a vártnál sokkal gyorsabban válhat a sebesen terjeszkedő kínai gazdasági erőtér „beltengerévé”.

A szövetségi rendszerek tekintetében is ellentmondásosan cselekedett a Trump kormányzat. A lecsúszó társadalmakra jellemző önzés és anyagi féltékenység attitűdjére támaszkodva, Trump az amerikai adófizetők érzékeny pontjára hatott akkor, amikor lényegében fölrótta az európai és ázsiai szövetségeseknek, hogy kiegyensúlyozott és biztonságos fejlődésük az amerikai véderő árnyékában az Egyesült Államokon való élősködés egyfajta kifinomult formája lenne. Donald Trump azt is kilátásba helyezte, hogy az Egyesült Államokat egyoldalúan kilépteti a NATO-ból, amely szervezetet idejétmúltnak minősítette. Ezzel bizonyára kivívta Moszkva mély szimpátiáját, főleg abban a kontextusban, hogy a Putyin-rendszert megvádolták a 2016-os amerikai választási kampányba való online-beavatkozással, hogy ezáltal elősegítsék a nyugati kohéziót gyengítő favoritjuk, Donald Trump politikai győzelmét. A Trumpot ért vádaskodások utólag visszatekintve elnagyoltnak tünnek, mert az ilyen, NATO-típusú, valóban közös érdekeken nyugvó stratégiai jelentőségü védelmi szövetségeket nem lehet olyan könnyen fölszámolni. Az elmúlt négy év válsága és Oroszország agresszor-percepciója csak növeli a kötőenergiát a NATO tagokban. Paradox módon Trump éles kritikája új életet lehelt a NATO-ba, ugyanis kétségtelen, hogy korábban számos tagállam, köztük gazdag, nagyméretü nyugati államok is, mint például Németország, ugyancsak elkényelmesedtek a szervezetben, alacsony fajlagos hozzájárulásukkal a kollektív biztonsághoz. A Trump által „fölrázott” NATO azonban valóban elindult a katonai kiadások meredek növelése útján, ami a tagállamok többségében 2024ig valóságossá teszi a GDP arányos védelmi ráfordítások legalább két százalékra való emelését.

A folyamatosan napirenden lévő kétoldalú konfliktusok terén a Trump kormányzat felemás eredményeket ért el, de mindenképp elkerülte az eszkalációt. Az észak-koreai kommunista diktatúrát megpróbálta pacifikálni, illetve a nukleáris felfegyverkezési programját tárgyalásos úton visszaszorítani. Átütő sikert nem ért el ebben a vonatkozásban, azonban mindenképp eredménynek tekinthető a párbeszéd beindulása és az észak-koreai kommunista rezsim is visszafogott a korábbi háborús retorikájából.

A 2020. év eleji iráni válságból is, ami a regionális háború küszöbére sodorta a feleket, az amerikai és iráni önuralom végül egyaránt hozzájárult ahhoz, hogy mederben lehetett tartani a konfliktust. A közel-keleti fölfordulás Trump elödeinek a „terméke”, de a Trump vezette Amerika az elmúlt négy esztendőben semmiképp sem járult hozzá a helyi konfliktusok kiterjesztéséhez, azok után, hogy koalícióban hozzájárult az Iszlám Állam időleges visszaszorításához. Összességében tehát megállapítható, hogy 2016 után az Egyesült Államok az egyik leginkább, átfogó háborúktól mentes rövid időszakát élte meg a hidegháború befejezése óta, és ez mindenképp a korábban démonizált Trump-adminisztráció érdeme. Ezek a premisszák, bár továbbra is sok a nehezen megoldható kérdés nemzetközi szinten, mindenképpen jobb alapot teremtenek a jövőben a béke megszilárdításához. A Közel-Keleten várhatóan megmarad, sőt fokozódhat Irakban az amerikai katonai jelenlét 2020-at követően, hogy az Egyesült Államok által létrehozott Irán-ellenes koalíció nyomatékot kapjon és elrettentő eröül szolgáljon úgy a síitafélhold, mind egy esetlegesen újjáéledő Iszlám Állam számára.

A trumpi időszak egy kockázatos fordulatokat vállaló, vegytisztán reálpolitikai megközelítést kölcsönzött az amerikai külpolitikának, ezáltal letért arról a hagyományos útról, 
mely az idealizmust egyfelől és - Brzezinski szóhasználatával - a materializmust (reálpolitikát) másfelől elegyítette. Elvonatkoztatott attól, az amerikai külpolitika hatékonyságát sokszor korlátozó szemponttól, hogy számos partnerétől értékelvű magatartást (demokrácia, emberi jogok, sajtószabadság) kérjen számon a belpolitikájukban ahhoz, hogy Amerika jóindulatát ezzel elnyerje. Ezzel sikerült egy olyan példátlan és csodával határos együttmüködést összehoznia a Közel-Keleten, mely egy akolba terelte Izraelt és néhány öböl menti, olajban gazdag arab államot, amelyek amúgy is regionális szövetségesei az Egyesült Államoknak. Az Egyesült Arab Emírségek, Bahrein, majd az afrikai Szudán is elismerték Izraelt és együttmüködési megállapodásokat kötöttek a zsidó állammal. 2020 őszén, bizonyos sajtóértesülések szerint, küszöbön áll egy újabb hagyományos amerikai szövetséges, Szaúd-Arábia és Izrael között egy, a föntiekhez hasonló megállapodás megkötése. Az említett államok többsége már korábban is, gyakorlatilag együttmüködött Izraellel a színfalak mögött a közös regionális ellenség, Irán ellehetetlenítésének és kordában tartásának szándékával. Az iráni atomalku fölrúgása az Egyesült Államok által így tágabb értelmezést nyer. Az amerikaiak ezzel valószínüleg olajozottabbá akarták tenni az utat az izraeli-arab megállapodások előtt. Az, hogy ezért átmenetileg ,zárójelbe tették" a palesztin ügyet és békefolyamatot, egy olyan mellékszála a történetnek, ami akár el is fajulhat, vagy, búvópatakként funkcionálva, rejtett frusztrációkat gerjeszt a térségben, egy jövőbeni robbanásveszéllyel. Ugyanígy veszélyeztetheti az így létrehozott taktikai koalíciót, ha erőltetik a Golán-fennsík Izraelhez csatolását, valamint a ciszjordániai izraeli telepek annexióját a zsidó államhoz, ami az arab szolidaritás jegyében elsődlegesen Szaúd-Arábia ellenséges föllépését váltaná ki.

Ugyanakkor az Iszlám Állam előretörése a megbuktatott Szaddam Hussein eltávolítása által keltett hatalmi vákuumban, valamint az egykori közel-keleti diktátorok fölváltása anarchikus belháborúkkal az arab tavasz eseménysorozatának következményeiként egyértelmüsítették az amerikai politikában, hogy a stabilitást hozó diktatúrák „kifizetődőbb” és kiszámíthatóbb viszonyokat teremtenek az amerikai érdekeknek is a térségben. Ezért a trumpi olvasatú nemzetközi kapcsolatokban, ,kijózanodott”, machiavellista hozzáállással, lemondtak az illúziókat kergető „,demokráciaexportról”. Mind az öböl menti arab olajtermelő államok, mind Szudán a legmegengedőbb esetben sem nevezhetők demokráciáknak, de a biztosabb kontúrokat kapó, új nemzetközi együttmüködési rendszerben tökéletesen megfelelnek az Egyesült Államok közelkeleti és globális célkitüzéseinek és nem utolsó sorban, képesek fönntartani a biztonságot és stabilitást. Mindazonáltal egyáltalán nem biztos, hogy a regionális szövetségi rendszer fölépítése és az Irán elleni közös föllépés kiélezése hosszú távon megérné az Egyesült Államoknak. Már Brzezinski is attól óvta az amerikaiakat, hogy ne alakítsanak ki egy olyan konstellációt, amely Kína, Irán és Oroszország ,együttállását” eredményezheti, még akkor sem, ha ez csak alkalmi taktikai póz lenne a három ország részéről (Brzezinski, 2017, p. 284). A jelenlegi állapot azonban pont ide vezethet, tekintve, hogy a hagyományos iráni-orosz szövetség mellett Kínát sem hagyja közömbösen ez a regionális játszma. 2020 őszén olyan hírek láttak napvilágot, hogy Kína egy brutális, 400 milliárd dollárt felölelő pénzügyi támogatással mentené ki az amerikai szankcióktól sokat szenvedett Iránt és hajlandó nagyhatalmi patrónusává szegődni, ezzel kiegyensúlyozva a térségben épülő amerikai koalíciót.

A jövő kétpólusú világrendjében Amerika csak úgy örizheti meg a vezető szerepét, ha a hidegháború utáni korszak második felétől kezdődően súlyosan és nagy sebességgel erodálódó hitelességét és megbízhatóságát helyreállítja. Az imázsvesztés az iraki unilateralista beavatkozás indokolatlan pusztításaival kezdődött. Folytatódott a 2008-as pénzügyi válság súlyos piaci torzulásaival, a dereguláció okozta piaci fundamentalizmus vadhajtásainak fertőző tovaterjedésével, amit a világ egyértelműen wall street-i eredetü, amerikai „betegségként” azonosított. Majd betetőződött a koronavírus-válság által is elmélyített belpolitikai, etnonacionalista fölfordulással 2020-ban, ami egy afroamerikai polgár rendőri intézkedés által kiváltott erőszakos halálával hozható összefüggésbe. Ezek a megmozdulások kísértetiesen emlékeztettek a 60-as évek polgárjogi mozgalmainak utcai harcaira, ami a hidegháború majd a vietnámi háború közepette tette kirívó módon próbára az amerikai társadalmat, és amiből az 
amerikai demokrácia végül megerősödve jött ki. A jelenlegi helyzetben, a botrányba fulladt 2020as elnökválasztás idején azonban alapvetően szkeptikusak vagyunk atekintetben, hogy a belharcok során felerösödött manicheizmus, a szekértáborok egymás iránti elvakult indulata és a törzsi alapon szerveződő társadalmi csoportok ijesztő fegyverkezése nem vezet-e végül társadalmi robbanáshoz. A megtépázott nemzetközi tekintély helyreállítása nélkül az Egyesült Államok nem játszthatja el a továbbiakban az erkölcsi fárosz szerepét sem szövetségesei, sem ellenfelei előtt. Csak egy, szövetségesei számára megbízható, otthon rendet teremteni képes, szilárd társadalmi cölöpökön nyugvó szuperhatalom őrizheti meg a jövőben a státusát, hogy a Spengler óta számtalan formában „fölmelegített” nyugati hanyatlás ne váljék önbeteljesítő jóslattá.

Ugyanakkor egy továbbra is fontos erőssége az Egyesült Államoknak a páratlanul vonzó amerikai soft power. Az amerikai életszínvonal, az egyén szabadsága és mozgástere, a populáris kultúra vibráló kisugárzása, amely elsősorban más országok fiataljait vonzza mágnesként és oda vezet, hogy a rivális Kínából és Oroszországból is inkább Amerikába vándorolnának ki a fiatalok.

Az amerikai partnerek közül a hozzá legközelebb álló szövetséges az Európai Unió, mely a hagyományos, demokratikus értékrendek és közös gazdasági érdekek mentén szerveződő területi integráció. Részben rátevődik a NATO-ra, de az Amerika számára legmegbízhatóbb partnerek a két szervezet (EU és NATO) metszetében helyezkednek el, a nyugati szövetségi rendszer belső körét képezve.

Ha Európát a továbbiakban a leegyszerűsítés kedvéért azonosítjuk az Európai Unióval, akkor a Trump-adminisztráció 2016-os hivatalba kerülése óta a transzatlanti kapcsolatok mindenképp hullámvölgybe kerültek. Először azért, mert a Trump-elnökség első félidejében valóban az „America first” tranzakcionalista szemléletének jegyében az Egyesült Államok haszonelvü módon az EU-val szemben is igyekezett csökkenteni kereskedelmi deficitjét egy kibontakozó kereskedelmi háború jegyében, illetve az amerikai terhek csökkentése fejében az európai NATO-tagok védelmi hozzájárulásának növelését követelte (amivel végül is jót tett a NATO önvédelmi képességéinek). Az elnökség második szakaszában azonban annyira kiéleződött az amerikai-kínai hatalmi rivalizálás és annyira erősödtek a kínai pozíciók, hogy az Egyesült Államokban az egoizmusa növekedésének közepette is mélyen tudatosult az a megkerülhetetlen fölismerés, hogy a Kína elleni föllépéshez abszolút nélkülözhetetlenné válik a nyugati világ egységben tartása és ehhez égetően szüksége van a továbbiakban is Európára. Ezért egy kifinomultabb külpolitikai elemzés felfedezi a folytonosságot a Trump elötti és alatti amerikai világpolitikai vezérfonal folytonosságában. A trumpi elnöki ciklus végén a németországi korlátozott csapatkivonás is megtévesztő lehet - ez inkább a Trumpot a gazdasági versenytársként és az orosz gazdasággal összefonódott „következetlen” szövetségesként irritáló Németország „megleckéztetését” szolgálta inkább. A kivont csapatok egy jelentős része a valós vagy vélt orosz fenyegetés föltartóztatása végett a kelet-európai szövetségesekhez lenne átcsoportosítva, elsődlegesen Lengyelországba és Romániába. Ez az amerikai csapatösszevonás és állomásoztatás Kelet-Európában sértené a NATO-Oroszország egyezményt, ez azonban az amerikai érvelés szerint nem áthidalhatatlan akadály és már az Obama-adminisztráció idején megkezdődtek az ilyen irányú lépések Oroszország föltartóztatása érdekében, különösen a krími orosz agressziót követően. Ugyancsak Lengyelországot és Romániát érintették az amerikai rakétaelhárító rendszerek telepítései a 2000-es évek végétől, amire Oroszország rakéta-telepítésekkel felelt, és ami fölgyorsította a folyamatot a Középható-távolságú Nukleáris Rakétaegyezmény 2019-es fölmondása irányába. Ez a tény, valamint az új típusú hiperszonikus nukleáris hordozóeszközök kifejlesztése egy korábban soha nem látott fegyverkezési verseny felé taszítja a világot.

A külpolitikai vonal folytonossága könnyüszerrel nyomon követhető a 2020-as amerikai elnökválasztás vitáiban is, ahol a jelöltek igyekeztek egymást túllicitáló módon bizonygatni, hogy ki lépne föl erélyesebben Kína ellen. Ehhez a föllépéshez az európai szövetségesekre is hiánytalanul szükség van, ezért a jövőben várható, hogy az Egyesült Államok megpróbál szigorúbban rendet tartani közöttük, hogy egyszólamúan igazodjanak a Kínával és Oroszországgal szembeni közös ellenállás frontján, ahogy azt Orbán Krisztián politikai elemző is kifejti (Forrás: https://www.youtube.com/watch?v=WI8VvMgUA1M). Ilyen értelemben csak részben tünik 
realistának Jean-Yves Le Drian, az EU külügyi biztosának inkább fatalista és defetista megjegyzése, hogy a Trump-érában irreverzibilis módon „megszakadt” valami a transzatlanti kapcsolatokban, ugyanis Európa szembesült a relatív magányával és avval, hogy csak magára számíthat, ha önvédelméről van szó. A föntebb vázolt logikával ellentétben, egyrészt a Trumpadminisztráció sem hagyta magára Európát, még ha érdesebb és kevésbé diplomatikus is volt a diskurzusa, csupán felelősebb részvételt csikart ki a közös terhek viselésében. A demokraták külpolitikája pedig a védelmi pillér mellett (NATO) vélhetően fontosnak fogja tartani - ezirányú tradícióit is figyelembe véve - az európai egység megszilárdítását is, ugyanis ebben, a republikánusokkal ellentétben, az össznyugati kohézió egy nagyobb támaszát látják.

Az európai politikai kohézió több okból is megroppant az utóbbi években. Egyrészt külső bomlasztó erők is ez ellen dolgoztak - lásd az orosz és kínai aktív titkosszolgálati tevékenységet és dezinformálást ezirányban. A migrációs válság, ami a fölrobbant Közel-Kelet irányából folyamatos fenyegetettséget jelent, tovább növeli az európai megosztottságot, hiszen nincs egységes migrációellenes stratégia, amiben a tagállamok megegyeznének. Az európai államok ellenállóképességét a migránsok által jelentett civilizatórikus, az együttélés szabályait feszegető mindennapi konfliktusok is próbára teszik, ugyanis a szekularizált, posztmodern korban az európai népek identitásmintázatai elhalványultak és ez a tény tompítja az immunrendszerüket önazonosságuk megőrzésében. A migrációs válság nyomában fölbukkant fokozott terrorfenyegetés, főként Európa nyugati felében, talán ráébreszti az Uniót egy határozottabb migrációellenes föllépés szükségességére, megpróbálva helyben kezelni a válságjelenségeket vagyis a kibocsátó kudarcállamok (failed states) pacifikálásával és segélyezésével. De fontosak a belső okok is ilyen értelemben, mint a 2008-as pénzügyi válság elhúzódó kezelése, főként a déli perifériák esetében (olasz, görög és ibériai akutizálódása a gazdasági válságnak). Ez utóbbi eset fölhívta a figyelmet a monetáris unió elhamarkodottságára, ugyanis a déli, integrációéretlen periférián az euró relatív fölülértékelt volt, ezáltal drasztikusan rombolta az euróövezethez csatlakozott déli tagállamok versenyképességét. Ugyanakkor az északi centrumországok gazdaságában a közös valuta relatív alulértékeltnek számított, ami halmozottan növelte korábbról meglévő versenyelőnyüket. Az ebből eredő regionális jövedelempolarizáció fokozta a feszültségeket a déli és északi tagállamok között, gyengítve az európai politikai „kötőenergiát”. Hasonló módon, nőtt a feszültség Közép- és Nyugat-Európa között, a Visegrádi 4-ek néven ismert regionális együttmüködési tömörülés és a francia-német tengely köré tömörülö országcsoport között, a képlékeny fogalmi határok között értelmezhető ,jogállamiság-vitában” és a koronavírusválság által keltett súlyos gazdasági visszaesés kezelési módjainak megválasztása körül. Nincs ugyanis megegyezés az európai fejlesztési pénzek ,jogállamisághoz” kötött kifizetése és az „Új Generációs” válságalap hosszú távú eladósodást generáló, „palliatív” krízismenedzsmentjének megítélése tárgyában.

Korábban a szintén endogén eredetü egoizmus képezte a fö felhajtóerőt a brexitben, mikor populista brit politikusok a Nagy-Britanniát a 2004-es bővítési hullám után elárasztó keleteurópai vendégmunkások ellen hangolva, és régebbi Európa-ellenes brit averziókat fölfrissítve véghezvitték az Egyesült Királyság kiválását az Európai Unióból. Ezek a viták belülről kezdik ki az európai egységet, további dezintegrációs folyamatok immanens veszélyét hordozzák magukban, és, amíg Európa nem tud nyugvópontra kerülni e belső viták tárgyában, addig nem lesz képes az integrált nyugati világ szereplőjeként sem megfelelni a versenytársaival vívott gazdasági és geostratégiai kihívásoknak sem. Itt az Európai Unió föladata ugyanaz, mint amerikai szövetségeséé, azaz erőfeszítéseket kell tennie belső viszonyainak normalizálása, illetve rendbe tétele, gazdaságának és önvédelmi képességeinek modernizálása érdekében, mert a nyugati világ második legfajsúlyosabb pilléreként csak így nyer hitelességet és tekintélyt a hatalmi centrumok vetélkedésében. Ez lehetővé tenné az új világrendben a kissingeri „hatalom és legitimitás” dialektikus egyensúlyának szimultán érvényesülését. A jövő kétpólusú világrendjében Európa Amerika egyfajta hátországaként fog funkcionálni, mint az eurázsiai rimlandra kiterjesztett amerikai hídfóállás, ami biztosítja Amerika tartós jelenlétét és érdekeinek érvényesítési lehetőségét a szuperkontinensen (Brzezinski, 2017, pp. 51-64). 
Az Egyesült Államok legjelentősebb potenciális regionális szövetségesei közül India kitüntetett szerepet játszhat. Az amerikai-indiai politikai közeledés látványosnak mondható az utóbbi években, nem utolsó sorban a közös ellenségként démonizált Kína elleni föllépés összehangolása reményében. India végletesen pragmatikus külpolitikát folytat, nem utolsó sorban a szun-ce-i hipermachiavellizmuson is túltevő indiai tudós, Kautilja állambölcseleti hagyományaira építve, aki a nemzetközi kapcsolatokban a hideg számítás elvét abszolutizálta (Kissinger, 2017, pp. 198-214).

Amerika napjaink indiai külpolitikai kapcsolatrendszerében ugyanazt a szerepet játszhatja el, mint a hidegháború alatti indiai szövetséges, a Szovjetunió. Vagyis India éppen azzal a hatalommal építi legaktívabban kapcsolatait, mely térségbeli természetes ellenségével, Kínával valamilyen tartósabb összetüzésbe kerül. Csakhogy India térségbeli geopolitikai egyensúlyát Pakisztán is veszélyezteti, akivel a függetlenség 1947-es kivívása óta területi vitákba bonyolódott kasmír hovatartozását illetően. Pakisztán a térségben ebből kifolyólag, nem véletlenül Kína egyik kulcs-szövetségese lett, aki azonban a hidegháború idején, párhuzamosan a kínai-amerikai közeledéssel, Amerikához is bizalmibb viszonyt épített ki. Ezért az Egyesült Államok számára nehéz döntés Pakisztántól eltávolodni, hiszen ez tovább növelné a fenyegető civilizációs és politikai szakadékot Amerika és az iszlám világ egésze közt. Taktikai és stratégiai megfontolások egyaránt India felé taszítják Amerikát, de az Afganisztáni puskaporos hordóhoz való jövőbeni hozzáférési lehetőség is, természetesen valamiféle ,rendcsinálási” célzattal, indokolttá teszi a Pakisztánnal való beszélőviszony fönntartását. Ez a beszélőviszony azonban mindenképp csorbulna egy esetleges kiépülő amerikai-indiai szövetség esetén. Mindezzel együtt, el kell ismernünk, hogy India és Pakisztán 1998 óta érvényre jutó atomhatalmi státusa jelentősen stabilizálta a régiót, miután a kölcsönös nukleáris elrettentés pacifikálta a versengő feleket.

India szerepe abból a szempontból is növekszik, hogy a gyorsan bővülő gazdasága és népessége révén Kína regionális hegemónia-törekvéseit nagyszerüen képes ellensúlyozni. Fegyverbeszerzéseinek iránya a korábbi orosz orientáció helyett fokozatosan áttevődik nyugati (elsősorban amerikai és francia) beszerzési források felé, ami hatalmas üzlettel kecsegtet. Nagyméretü flottafejlesztése az Indiai-óceán fölötti katonai egyeduralom-szerü ellenőrzést is lehetővé teszi, blokkolva Kínát ebben a nagytérségben és tehermentesítve ezáltal az amerikai flottát is, mely ily módon inkább koncentrálhat a Csendes-óceán ellenőrzésére. A vázolt geopolitikai előzmények láttán nem csoda, hogy India és Kína kölcsönös bekerítéssel vádolják egymást.

Japán a második világháborúban elszenvedett vereségét követően amerikai gyámolítás mellett épült újjá és vált olyan meghatározó gazdasági világhatalommá, mely egy adott pillanatban az amerikai világgazdasági elsőbbséget is fenyegette. Technológiai-gazdasági szárnyalása az önként vállalt pacifizmus miatt nem járt együtt a hidegháború éveiben és azt követően sem újrafölfegyverkezési ambíciókkal. Az egyszázalékos GDP-arányos, szerény katonai kiadások, jobbára az ütőképes, szigorúan védelmi doktrínájú flottafönntartást tették eddig lehetővé. Japán békés és gyors, háború utáni fejlődését gyakorlatilag az amerikai biztonsági garanciavállalások tették lehetővé, melyek Japánt úgy egy potenciális szovjet agressziótól, mint egy jelenlegi kínai fenyegetéstől megvédik. A Trump-kormányzat éveiben jelentős bizalomvesztés veszélyét hordozták magukban azok az amerikai szándékok, melyek az Európa esetében már ismertetett analógiára alapozva „megsarcolták” volna Japánt az amerikai védelmi ernyő szolgáltatásaiért cserébe. Ez alapjaiban ásná alá az Egyesült Államok szövetségesi megbízhatóságát és Dél-Korea biztonságérzetét is megingatná. Nem csoda, ha Dél-Korea, demokratikus berendezkedése mellett mindig nyitva hagy egy párbeszéd-kaput Kína irányába is, hogy az amerikai szövetségesi kötelezettségek megkérdőjeleződése esetén Kínához forduljon védelmi garanciákért északi szomszédjával szemben. Ennek fényében az amerikai-japán viszonyt is az amerikai szerepvállalás teljes kontextusában kell vizsgálnunk a kelet-ázsiai régió egészében. Ez a kapcsolatrendszer ugyanis a katonai haditengerészeti támaszpontok és az amerikai szárazföldi katonai jelenlét tükrében hozzájárul Kína tengeri föltartóztatásához a Csendes-óceán térségében és szimmetrikus párját képezi az eurázsiai „világsziget” nyugati hídfóállásának, amit az Észak-atlanti Szövetség 
európai katonai jelenléte testesít meg. Ugyanakkor Kína páratlanul gyors fölemelkedése behódolás által is „,beszippanthatja” a térség államait a kínai érdekszférába, ami a klasszikus amerikai szövetségesekkel is megtörténhet, különösen, ha az amerikai biztonsági elkötelezettség meginogni látszik. Egy ilyen szcenárió a huntingtoni katasztrófa-forgatókönyvekben is megvalósult. Huntington ugyanis a legvalószínübb amerikai-kínai konfliktusforrásként, ami egy utolsó világégés kiinduló alapját is jelentené, a Tajvan körül kibontakozó amerikai-kínai lehetséges összecsapást látja, amit egy Vietnám elleni jövőbeni kínai invázió vált ki, és ahol Tajvant már bekebelezte Kína (Huntington, 2012, pp. 465-466). Ebben a konfliktusban a kínai hatalmi „gravitáció” által „behúzott” és önalávetést gyakorló Japánt már nem amerikai, hanem kínai oldalon harcoló félként tünteti föl Huntington. Személyes megítélésünk szerint, erre vajmi kevés esély van, ugyanis a második világháborús számvetést el nem végző Japán és a viszonylatában nyílt revansizmussal megnyilvánuló Kína kapcsolatrendszerében a megbékélés hiányában nem lehet ilyen pálfordulatra számítani. Sokkal inkább az valószínüsíthető, hogy az, egy ideje már napirenden lévő japán védelmi-kiadásnövelő szándékok valósággá válnak a fenyegetésnek érzékelt kínai térségi előretörés láttán. Ebbe még egy Japán atomfegyverkezés is belefér, az amúgy is elszabadult nukleáris proliferációs válság következményeként, amit az ÉszakKorea által Japán számára jelentő atomfenyegetés is indokolttá tehet. Mindez a saját lábon állás persze csökkentené az amerikai szerepvállalást Japán biztonságának garantálásában, ugyanakkor növelné a biztonságpolitikai egyensúlytalanságot a térségben, ami nem egyezik az amerikai érdekekkel. Ez is tehát egy olyan dilemmatikus helyzet a Távol-Keleten, amit Kína föltartóztatása és elrettentése során az Egyesült Államok valószínüleg figyelembe fog venni.

A fokozódó technológiai versengés közepette, egy új kétpólusú világrend korlátozott hidegháborújában nem kizárt a technológiai föltartóztatás eszközével való próbálkozás sem, amit sommásan egy „új Cocom-listaként” tudnánk értelmezni. A Huawei és Android körüli technológiai háború ennek a kötélhúzásnak az előjátékaként is értelmezhető és Amerikában, politikai hovatartozástól függetlenül, nagy egyetértésben hajtotta végre a Trump-kormányzat ezt a büntető intézkedését Kína ellen. Az összehangolt „új Cocom-lista” érvényesítését azonban az Egyesült Államok nem viheti végbe Európa és Japán szövetsége nélkül. Ugyanakkor Kína gyors fölzárkózása megkérdőjelezi ennek hatékonyságát, nem biztos, hogy a kínaiaknak szükségük lesz egy idő után a nyugati technológia-transzferekre, hogy lekörözzék az Egyesült Államok és általában a Nyugat ilyen irányú képességeit. Retrospektív módon meg szoktuk mosolyogni Hruscsov hatvanas években hangoztatott célkitüzését, hogy a Szovjetunió a nyolcvanas évekre le fogja körözni az Egyesült Államokat. Ma azonban a kínai fejlődés és gazdasági-hatalmi hegemóniaváltás egyfajta elkerülhetetlen determináció, ami a szovjet modernizációs kísérlettel szemben sikerre van ítélve. Hiú ábránd lenne nyugati részről abban reménykedni, hogy a kínai fejlődés megáll, belátható időn belül lelassul, vagy a visszájára fordul, mint ahogy megfogalmazódtak ilyen hamis várakozások még a kilencvenes évek végén is Kínával szemben. Kína a Szovjetunióval ellentétben nem „fárasztható ki” egy erőforrás-versengésre alapozott új, korlátozott hidegháborúban. Sőt, meg merjük kockáztatni a föltevést, hogy egy olyan reverzibilis helyzet is kialakulhat már középtávon is, hogy Kína próbálja korlátozni a nyugatiak hozzáférését bizonyos saját fejlesztésü, magas tudástartalmú technológiai termékeihez.

A legtöbb, amit várhat az Egyesült Államok egy ilyen szembenállástól, hogy egy gondosan összekovácsolt szövetségi rendszerben tartósan föltartóztatja Kínát. Ebben az értelmezésben az Egyesült Államok valószínüsíthetően a koronavírus-válság által fölfokozott nemzetközi versengésben azt a szerepet fogja eljátszani, amit egykoron Anglia játszott el a világtörténelemben már Orániai Vilmos óta, vagy amit Nagy-Britannia létrehozott a Bécsi kongresszuson a nagyhatalmi koncert keretében (Kissinger, 2013, pp. 46-49). Magyarán csakis egy fentebb vázolt szövetségi rendszer élén lesz képes a Nyugat-centrikus hatalmi állagőrzést úgy biztosítani, hogy az gazdasági-politikai érdekeinek egy folytonos védelmét fönntartsa.

Fontos ebben az egyensúly-politikában a nagyfokú amerikai rugalmasság. Kérdés ugyanis, hogy úgy kezeli-e majd Amerika Kína fölemelkedését, ahogy az első világháború előtti merev szövetségi rendszerek kezelték félre a vilmosi Németország hatalom-gyarapodását, ami 
végül az első világháború kitöréséhez vezetett? Amennyiben ez a rugalmasság és egyensúlyi politika sikeresen megvalósul, ez képezheti a jövő új, kétpólusú világrendjének az alapját, amelyben, reményeink szerint, a béke fönntartható lesz.

Végül fölvetődik egy lehetőség a Brzezinki-féle értelmezésben a „nagyobb Nyugat” megteremtésére, amiröl korábban már szóltunk, és amelyet szintén az Egyesült Államok kellene elsődlegesen kezdeményezzen. Ez lehetőséget adna távlatilag Oroszország és Törökország integrálására értékalapon is a szükebben értelmezett nyugati közösségbe. Brzezinski ilyen irányú projekciói rövidtávon sajnos illuzórikusnak bizonyultak, mert Oroszország agresszív hatalmi politikája Ukrajnában és Szíriában, illetve az ennek következtében bevezetett nyugati szankciók megmérgezték a kapcsolatrendszert és időben eltávolították ennek megvalósulási esélyeit. Oroszország azonban távlatosan komoly konkurenciát láthat maga is Kínában, ami a Nyugat felé taszíthatja majd. Törökország is fokozatosan idegenedett el a Nyugattól, föként az elképzelhetetlenül elhúzódó európai integrációs fiaskója miatt, miután az évtizedekig tartó belépési tárgyalások végén sem kapta meg az integráció-érettségi minősítést. Ebben az Uniónak is megvan a maga felelőssége, elsősorban Franciaország és Németország ellenállása miatt, akik túl nagy és nehezen „emészthető” tagjelöltnek tartották Törökországot. A törökök frusztrációja egy reakciós magatartást szült egy olyan vezető részéről, akinek birodalmi nosztalgikus tervei vannak és Törökország iszlamizálódását is elöre lendítette (Brzezinski, 2017, pp. 187-216). Recep Tayyip Erdogan Törökország szomszédjainak többségét háborúval fenyegeti. Az elmúlt években Szíriába közvetlenül beavatkozott katonailag, Örményországba úgyszintén, Azerbajdzsán oldalán, és a hagyományos rivális, NATO-szövetséges Görögországot is katonailag fenyegeti egy, a Földközi-tengeren található vitatott hovatartozású gázmező okán. Az Európai Uniót 2020-ban nyíltan zsarolta olyan migránsokkal, akiknek szabad elvonulást engedett volna az Unió felé, és akiket végül Görögország tartott vissza. Törökország ebben a lépésében, nem alaptalanul, az elégtelen nyugati pénzügyi támogatást rótta föl. Ezek az események végletesen eltávolították Törökországot a Nyugattól és destabilizátori szerepkörben tüntetik fel, ami lehetetlenné teszi a közeljövőben, hogy a Brzezinski-féle „,nagyobb Nyugat” elképzelés eséllyel kecsegtessen. Ennek ellenére, távlatosan a demokratizálódási folyamat kiterjesztése Oroszország és Törökország irányába természetes módon a nyugati integráció felé kellene, hogy vezesse ezeket az országokat. $\mathrm{Az}$ európai uniós tagság valós esélye természetesen kétségbe vonható, számtalan kulturális affinitás hiánya miatt, azonban a közös védelmi rendszerhez és szoros partnerséghez való tartozás a feleknek kölcsönösen elönyös és kifizetődő állapotot teremtene. Ehhez hozzájárulhat, hogy Oroszországban és Törökországban egyaránt széleskörü nyugatos értelmiség és fiatal generáció van jelen, akik éreznek magukban szándékot és nyitottságot afelé, hogy országaik jövőbeni politikai orientációját ebbe az irányba tereljék, minthogy racionális érdekeik ezt diktálják.

\section{Következtetések}

Egy ilyen tanulmány megírásában, az összes tárgyilagossági követelménynek való megfelelésigény mellett is óhatatlanul elötérbe kerül egyfajta intuitív szubjektivizmus, föként, ha a jelenben vázolt premisszák jövőbeni lehetséges fejlödési pályáit is kivetítjük. Kísérletet tettünk egy történelmi pályaív vázolásával, a közelmúlt hangsúlyosabb geopolitikai történéseinek fölnagyításával a jövő várható világrendjét legalább alapvonásaiban előre jelezni. Az objektivitás a kritikai olvasatban is igyekezett kibontakozni azáltal, hogy a kritikai szellem a részvevő aktöröket mindkét oldalon célba vette.

Elsődleges következtetésünk, korunk sok bizonytalansága ellenére is, pozitív olvasatú próbál lenni, minthogy a koronavírus-válság s az ebből származó társadalmi és politikai válságok nem szükségképpen csak negatív hatásúak. A válságok katalizátorként hatnak az emberek kreatív megoldás-keresésére, a válságok által okozott emberi szenvedés és ínség egyfajta drive-ként funkcionálhat a társadalmi szolidaritás és segítőkészség mobilizálására. A 2008-as pénzügyi válságon is úrrá lehetett lenni és közben a hibákból is rengeteget tanultunk. A koronavírus keltette negatív gazdasági hatások új gazdaságélénkítő módozatok és innovatív megoldások kialakítása 
felé nyithatnak utat. Ugyanígy forradalmasíthatják például a virológiát is, új, hatékonyabb terápiákat téve elérhetővé a fertőző betegségek kezelésében. A válság mozgósít, erős motivációt ad, növelheti a társadalmi kohéziót is, az emberek élni akarását, amellett, hogy számtalan kedvezőtlen jelenséget produkál. A koronavírus-válság második hullámában egy új rivalizálási jelenség ütötte föl a fejét, amit sommásan csak ,,vakcina-nacionalizmusnak” nevezhetünk, aminek a lényege, hogy amerikai-német, kínai és orosz oltások versenyeznek egymással a primátusért. A hatalmi-üzleti vetélkedésen túl ez is lehet egy olyan felhajtőerö, ami a gyorsabb és hatékonyabb járvány-védekezés felé nyitja meg az utat. Minden esetre a jövőben a biztonság megteremtése, és azon belül is a biológiai-közegészségügyi rizikók kiemelt kezelése sokkal nagyobb figyelmet fog kapni világszerte.

A második világháború lezárásáig a világrend lényegileg azonosult az európai nagyhatalmi renddel. Az itt meghatározott hatalmi hierarchiákat olyan békekongresszusokon határozták meg, mint a Bécsi Kongresszus vagy a versailles-i békekonferenciák. Az legújabb világrendek békés átalakulások, súlypont-eltolódások következményei is lehetnek, nem szükségszerü ezt háborús katasztrófának megelőznie. Ez az új világrend azonban már Ázsiaközpontú, Európa vitathatatlanul háttérbe szorult a globális játékosok porondján. Ehhez az Ázsiaközpontú új világrendhez az Egyesült Államok kívülről fog hozzákapcsolódni, mint második hatalmi központ, de a nemzetközi interakciói is azt fogják célba venni, hogy miként alakuljanak az Amerika számára releváns politikai események és viszonyrendszerek Eurázsiában.

Tanulmányunk abból indul ki, hogy a növekvő antagonizmus a jövőbeni két vezető hatalom között az új világrendet kétpólusossá alakítja a huszonegyedik században, ami a hatalmi versengés kiéleződése folytán egy új, korlátozott hidegháborút eredményez majd a hatalmi tömbök között. A két pólus Kína és az Egyesült Államok lesz. Az új hidegháború korlátozott jellege pedig abból adódik, hogy a köréjük szerveződő két rivális tömb között összehasoníthatatlanul nagyobb lesz az átjárás, mint az ideológiailag egykor szemben álló szocialista és kapitalista szövetségi rendszerek közt. A kétpólusosság mellett várhatóan felértékelődnek a másodlagos regionális hatalmak, melyek részben szintén csatlakozhatnak a két pólus valamelyikéhez (India, Irán, Pakisztán, Indonézia, Brazília). Más szóval, fragmentáltabbá válik a világpolitika a hatalom megoszlása tekintetében.

Kína puszta méreténél fogva is egy új, hiperhatalmi minőséget jelenít majd meg a világpolitikai viszonyrendszerben. Az általa dominált világrendben a példátlan mérete már olyan befolyást jelent, ami nagyon sok államot önkéntes behódolásra késztetne. Fölszálló ágban lévő fejlődése semmi szinten nem vethető össze a méreteiben sokkal kisebb Szovjetunió vagy Egyesült Államok korábbi fejlődéséhez, amikor összehasonlítható méretü szereplők versenyeztek egymással. Teljes hiperhatalmi kibontakozásának egyetlen akadálya az lehet, mennyire kreatívan képes az Egyesült Államok egy ellenállási gyürüt szervezni köréje az eurázsiai rimlanden, egy új, ámde rugalmasabb, „átjárhatóbb”, föltartóztató hidegháborúval. Fölemelkedése megakadályozhatatlan, nem lehet - a szovjet példával ellentétben - a kifáradásán vagy a kifárasztásán alapuló spekulatív számításokra alapozni. Technológiai fölényre is könnyüszerrel szert tehet, ami szintén megismételhetetlenné teszi egy amerikai hidegháborús győzelemszcenárió újrajátszását. Magatartásának megváltozása, agresszívabbá válása, egy nacionalista kurzus előtérbe helyeződése a mostani kiegyensúlyozottabb diskurzussal szembe oly mértékben növelheti a Kína körüli feszültségeket, hogy az első világháború előtti merev szövetségi rendszerek kialakulásához vezethet, és világégés kirobbanását lehet ezzel kockáztatni. Eddig a szun-ce-i bölcsességre alapozva valós hatalmi szándékait úgy is rejtette, hogy példának okáért a jövőstratégiáikban a kínaiak is igyekeztek kerülni a „fölemelkedés” fogalmat - helyette inkább a „fejlődés” kifejezést használták, hogy ne keltsenek riadalmat riválisaikban (Kissinger, 2014). Ezidáig bölcsen, csupán gazdaságilag akarta meghódítani a világot, a puszta növekedéséből adódó roppant méretével kívánt imponálni. Hszi Csin-ping kínai elnök azonban a 2010-es évek második felétől, az amerikai kereskedelmi háborús kihívás hatására is egy olyan konfrontatív, nyugatellenes retorikára váltott, ami nagymértékben növeli riválisaiban az összetartó kohéziót a kínai valós vagy vélt fenyegetésekkel szemben. 
Oroszországban egy politikusi generációváltás és a nyugatosabb, fiatalabb, új politikusi elit hatalomra kerülésével képzelhető csak el egy politikai paradigmaváltás, ami a Nyugattal való kiegyezés és megbékélés irányába hathat. Oroszországnak mindenképp egy másodlagos szerep jut bármilyen szövetségi vagy lazább együttmüködési rendszerben. Mindez azzal magyarázható, hogy gazdasági és katonai képességei jóval szerényebbek, mint az Egyesült Államoknak vagy Kínának. Oroszország már soha nem játszhatja el azt a szerepet, mint a Szovjetunió vagy a cári birodalom idején, mert a szabadságot megízlelt, egykori birodalmához tartozó népek önként soha nem fogják gyakorolni a behódolást vagy az önalávetést. Az oroszok kiegyensúlyozott fejlődése akkor lesz biztosított, ha hatalmas területüket védve látják, és jelenlegi védelmi képességeik, nukleáris elrettentő erejük bárkit képes távol tartani egy meggondolatlan támadástól Oroszország ellenében. Ha képesek leküzdeni ezt a valótlan fenyegetettség-érzést, ha a birodalmi nosztalgiájuk elé helyezik a békés, belső erőforrásokra és nemzetközi együttműködésre alapozó fejlődést, akkor Oroszország számára is elérhető lesz az oly régóta áhított harmónia. Leginkább a Brzezinksi-féle „nagyobb Nyugatba” való beépülés jelentené Oroszország számára is a tartós egyensúlyt, mert egyrészt kulturális affinitások alapján is megalapozott lenne ez a kapcsolatrendszer, másrészt a Kína által eljátszott hiperhatalmi szerep csak így egyensúlyozható ki igazán globális szinten.

Az Egyesült Államok a Kínával szembeni föltartóztatás érdekében valószínüsíthetően egy nemzetközi koalíciót igyekszik majd létrehozni, melynek kiinduló bázisa a NATO és az Európai unió lesz a kulturális közelségek és a tradicionális kapcsolatok meghatározottsága révén is. A koronavírus-válság kiélezte a Kínával való verbális összetüzéseket és egy propagandaháború révén is fokozta a kibontakozó geopolitikai rivalizálást, Itt mindenképp meg kell állapítanunk azonban Kína elvitathatatlan felelösségét a világjárvány kirobbantásában. Ugyanakkor a diktatúrák esetenként nagyobb hatékonysággal tudnak föllépni a válságkezelésben, az erőszakszervezeteik határozottabb cselekvése folytán. Ezt tette Kína is, mikor stabilizálta a koronavírus-válságot és tovább fokozta ezáltal társadalmi-gazdasági előnyeit nemzetközi versenytársaival szemben.

A járvány gazdasági hatásai megtépázták az Egyesült Államok világgazdasági pozícióit és a 2008-as pénzügyi válsághoz hasonlóan aláásták az amerikaiak korábban megkérdőjelezhetetlen gazdasági hatalmát és pénzügyi súlyát. A járvány társadalmi-gazdasági hatásai megbuktatták a Trump-adminisztrációt, melynek külpolitikáját ellentmondásosnak ítélték, végső mérlegében azonban mégis pozitív kicsengésü volt, minthogy az egyik legbékésebb amerikai időszakot jelentették ezek az évek. A Trump-kormány alatt az Egyesült Államokat nemzetközi kapcsolataiban a pragmatikus ideológiai önmegtartóztatás jellemezte a haszonelvü együttmúködések mentén. Az Egyesült Államoknak a jól fölfogott érdekei is azt diktálják, hogy a kínai előrenyomulás hatékony föltartóztatáshoz és forrongó térségek stabilizálásához ne erőltesse a korábbi „demokrácia exportot”, mint ahogy ezt a közel-keleti sikeresen összehozott Irán-ellenes koalíció is bizonyítja. Ennek fényében, megítélésünk szerint az Egyesült Államok magatartására egyfajta kettős mérce megjelenése lehet jellemző a jövőben, ami a demokratikus elköteleződést csak a szükebb, nyugati szövetségi rendszeren belül kéri majd számon. Hasonlóképp a szükebb, nyugati szövetségi rendszeren belül határozottabban számon kérhet egyfajta ,intra muros” szövetségi lojalitást, ami korlátozni fogja a szövetségesek külpolitikai mozgásterét Oroszország vagy Kína irányába.

Az Egyesült Államok és az Európai Unió egyaránt nem spórolhatja meg a hazai ügyek rendbetételét. Az amerikai belső, anarchikus politikai szélsőségek lecsillapítása, az oktatási rendszer színvonalának emelése, az elmaradt infrastruktúra-fejlesztések pótlása és a piaci fundamentalizmus megzabolázása mind elmaradhatatlan feladatok, hogy az amerikai nemzetközi presztízs is helyreálljon. Az Egyesült Államok egyidőben kell törekedjen a hazai és külföldi stabilitás, illetve politizálás sikerességére, mert a külső és belső tényezők kiegészítik egymást, egymás függvényei, fölerősítik, illetve gyengítik egymás hatásait, egyfajta politikai szinergia formájában. Az Európai Unió határozottabb, migrációt föltartóztató politikája és terrorellenes föllépése sokat segíthet a politikai kohézió erősítésén is. És mindkét hatalmi pólus kigondolt 
gazdasági-válságkezelő csomaggal kell előálljon a koronavírus válság kezelésére, ami növekvő költséginflációt vetít elöre.

Ha a Nyugat nem hajtja végre a fönn vázolt, égetően fontos reformjait, akkor a hanyatlásáról szóló regék önbeteljesítő jóslatokká válhatnak, noha ez a hanyatlás nem kellene egy egyértelmü fatalista determináció legyen. Kellő akarattal, körültekintéssel és cselekvéssel elkerülhető. Az amerikai hanyatlás esetleges folytatódása és az ebből levezethető izolacionizmus, valamint cselekvésképtelenség az új kétpólusú világrend fönntartásában egy ellenőrizhetetlen nemzetközi káosz kirobbanásával fenyegetnek már középtávon. Ehhez a káoszveszélyhez a globális problémák, a nagyhatalmi kötélhúzás, a fenyegető klímakatasztrófa és a járványok egyaránt hozzájárulnak. Kérdés, hogy Kína be tud-e lépni rendcsinálóként ennek a nem kívánt, új káosznak a fölszámolásába/elkerülésébe és kialakul-e ennek következtében az új egyensúly, a „pax sinica”, új nemzetközi játékszabályokkal, melyek átformálhatják a hatalom és legitimitás örök viszonyrendszerét?

\section{Irodalomjegyzék}

BENNER T. - GASPERS J. - OHLBERG M. - POGGETTI L. - SHI-KUPFER K. (2018), Authoritarian Advance. Responding to China's Growing Political Influence in Europe, Mercator Institute for China Studies \& Global Public Policy Institute, Berlin.

BRZEZINSKI, Z. (2013), Stratégiai vízió. Amerika és a globális világ válsága, Antall József Tudásközpont, Budapest

BRZEZINSKI, Z. (2013), A nagy sakktábla, Amerika világelsősége és geopolitikai feladatai, Antall József Tudásközpont, Budapest

GERNET, J. (2005), A kínai civilizáció története, Osiris kiadó, Budapest

HORVÁTH G. - PROBÁLD, F. - SZABÓ P.(szerk.) (2018), Ázsia regionális földrajza, ELTE Eötvös Kiadó, Budapest, p. 464-473

KENNEDY, P. (2011), Ascensiunea și decăderea marilor puteri, Editura Polirom, Iași

KISSINGER, H. (2013), Diplomația, Editura All, București

KISSINGER, H. (2014), Kínáról, Antall József Tudásközpont, Budapest

KISSINGER, H. (2017), Világrend, Antall József Tudásközpont, Budapest

HUNTINGTON, S. (2012), Ciocnirea civilizațiilor și refacerea ordinii mondiale, Editura Antet, București

PROBÁLD, F. (2004), Amerika regionális földrajza, Trefort kiadó, Budapest

PROBÁLD, F. (2008), Ázsia regionális földrajza, ELTE Eötvös kiadó, Budapest

SZ. BÍRÓ, Z. (2019), Putyin Oroszországa, Noran Libro kiadó, Budapest

\footnotetext{
***https://www.youtube.com/watch?v=WI8VvMgUA1M - megtekintve 2020.05.20

***https://index.hu/kulfold/2020/07/17/iran_kina_szerzodes_szankciok_kozel-kelet/_ megtekintve 2020.07.20

***https://penzcsinalok.transindex.ro/globalis/20201002-kina - megtekintve 2020.10.05

***https://radingeconomics.com/china/gdp-growth-annual - megtekintve 2020.10.20

***https://www.imf.org/external/datamapper/NGDP_RPCH@,WEO/USA - megtekintve 2020.10 .20

***https://www.cnbc.com/2020/09/30/us-gdp-q2-2020.html - megtekintve 2020.10.20

***https://tradingeconomics.com/russia/gdp-growth-annual - megtekintve 2020.10.20

***https:/eletmod.transindex.ro/?cikk=13241 - megtekintve 2020.10.25

***https://www.youtube.com/watch? $\mathrm{v}=\mathrm{szVrKJ}$ rvmjA - megtekintve 2020.11.01

***https://novekedes.hu/elemzesek/mikor-lesz-a-kinai-juan-a-kovetkezo-dollar - megtekintve 2020.11.01
} 